\title{
Melanoma genetics
}

\author{
Jazlyn Read, ${ }^{1,2}$ Karin A W Wadt, ${ }^{3}$ Nicholas K Hayward ${ }^{1}$
}

${ }^{1}$ QIMR Berghofer Medical Research Institute, Brisbane, Queensland, Australia

${ }^{2}$ The University of Queensland, Brisbane, Queensland, Australia

${ }^{3}$ Department of Clinical Genetics, University Hospital of Copenhagen, Copenhagen, Denmark

\section{* Correspondence to} Dr Jazlyn Read, QIMR Berghofer Medical Research Institute, PO Royal Brisbane Hospital, Herston, QLD 4029, Australia; jazlyn.read@ qimrberghofer.edu.au

Received 25 March 2015 Revised 4 August 2015 Accepted 8 August 2015 Published Online First 3 September 2015

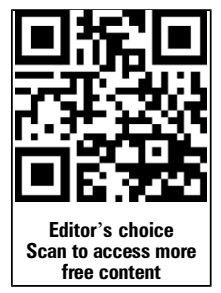

\section{CrossMark}

To cite: Read J, Wadt KAW, Hayward NK. J Med Genet 2016;53:1-14.

\section{ABSTRACT}

Approximately $10 \%$ of melanoma cases report a relative affected with melanoma, and a positive family history is associated with an increased risk of developing melanoma. Although the majority of genetic alterations associated with melanoma development are somatic, the underlying presence of heritable melanoma risk genes is an important component of disease occurrence. Susceptibility for some families is due to mutation in one of the known high penetrance melanoma predisposition genes: CDKN2A, CDK4, BAP1, POT1, ACD, TERF2IP and TERT. However, despite such mutations being implicated in a combined total of approximately $50 \%$ of familial melanoma cases, the underlying genetic basis is unexplained for the remainder of high-density melanoma families. Aside from the possibility of extremely rare mutations in a few additional high penetrance genes yet to be discovered, this suggests a likely polygenic component to susceptibility, and a unique level of personal melanoma risk influenced by multiple low-risk alleles and genetic modifiers. In addition to conferring a risk of cutaneous melanoma, some 'melanoma' predisposition genes have been linked to other cancers, with cancer clustering observed in melanoma families at rates greater than expected by chance. The most extensively documented association is between CDKN2A germ line mutations and pancreatic cancer, and a cancer syndrome including cutaneous melanoma, uveal melanoma and mesothelioma has been proposed for $B A P 1$ germ line mutations. Other medium to high penetrance melanoma predisposition genes have been associated with renal cell carcinoma (MITF, BAP1) and glioma (POT1). These associations between melanoma and other cancers hint at the possibility of common pathways for oncogenesis, and better knowledge of these pathways may improve understanding of the genetic basis underpinning familial melanoma. It is likely that 'melanoma' risk genes will impact on mutation screening and genetic counselling not only for melanoma but also a range of other cancers.

\section{INTRODUCTION}

The concept of melanoma risk is dynamic and multifaceted, owing to the diverse aetiology and heterogeneous nature of the disease. Genetic, phenotypic and environmental risk factors all contribute to melanoma predisposition. The majority of alterations underlying the genetic basis of this disease occur as random acquired mutations within melanocytes, and an accumulation of genomic changes contribute to melanoma development, progression and evolution. However, the presence of heritable germ line variants is an important component of melanoma susceptibility. ${ }^{1}$ Genes that predispose to melanoma are typically grouped into low, medium and high penetrance genes. ${ }^{2}$ Penetrance relates to the likelihood of a mutation carrier developing the disease over time, and reflects the overall contribution of a specific gene polymorphism, or mutation, to melanoma risk. Although no single presently known germ line alteration guarantees melanoma development, the main impact of predisposition genes is the elevation of baseline melanoma risk. For an individual with moderate to high genetic susceptibility, it is likely that fewer somatic mutations are required to accumulate before a critical level for oncogenesis is reached. Additionally, melanoma risk genes may interact directly with other genes or environmental risk factors to influence and activate melanoma growth pathways. ${ }^{13}$

A positive family history is associated with an increased risk of developing melanoma, and is particularly significant when there is a first-degree relative with multiple primary melanomas, or single primary melanomas in two or more first-degree relatives. ${ }^{1}$ The most common gene implicated in familial melanoma is cyclin-dependent kinase inhibitor 2A (CDKN2A), accounting for predisposition in approximately $20-40 \%$ of melanoma families. ${ }^{1}$ Despite a handful of other known high penetrance genes, many cases of familial melanoma are not accounted for molecularly, and the genetic basis for susceptibility remains unexplained for a large percentage of families. This suggests a likely polygenic mechanism of inheritance, including multiple low-risk alleles and genetic modifiers, as well as the possibility of rare mutations in other high-penetrance genes yet to be discovered. The risk genes that underpin familial melanoma may also be relevant to other cancers. Familial clustering of additional cancers has been observed in melanoma families, particularly pancreatic cancer linked to CDKN2A mutations, and the evidence for melanoma being part of broader cancer syndromes is mounting. ${ }^{14}$

\section{HIGH PENETRANCE GENES}

\section{Cyclin-dependent kinase inhibitor $2 \mathrm{~A}$}

The CDKN2A gene on chromosome 9p21 consists of four exons that encode two unrelated proteins in different reading frames arising from alternatively spliced transcripts. p16 inhibitor of cyclindependent kinase 4 ( $\mathrm{p} 16 \mathrm{INK} 4 \mathrm{~A})$ is produced from the $\alpha$ transcript of exons $1 \alpha, 2$ and 3 , whereas 14 alternate reading frame ( $\mathrm{p} 14 \mathrm{ARF}$ ) is produced from the $\beta$ transcript of exons $1 \beta, 2$ and 3 . The main tumour suppressor activity of p16INK4A is through inhibition of cyclin-dependent kinases 4 and 6 (CDK4 and CDK6), thus maintaining retinoblastoma protein (RB) in a hypophosphorylated state to prevent cell cycle S-phase entry. ${ }^{5}$ p14ARF is a positive regulator of $\mathrm{p} 53$, and therefore a loss of p14ARF allows for accumulation of DNA damage as cells escape the senescence barrier. ${ }^{5}$ The 
structure of $C D K N 2 A$ into two reading frames means that mutations can affect either p16INK4A, p14ARF or both, depending on which exon is affected. Autosomal dominant inheritance of germ line CDKN2A mutations has been implicated in approximately $20-40 \%$ of familial melanoma, although the mutation frequency varies between different geographical regions. ${ }^{5}$

Geographically linked founder mutations have been documented, with some occurring as a single predominant mutation based on common ancestry. CDKN2A founder mutations have been found in Sweden and the Netherlands, namely $p$. Arg112dup and p16-Leiden, respectively, both located in exon 2 and originating in northern Europe approximately 2000 years ago. ${ }^{6}$ Another dominant variant has been identified in Iceland, with G89D mutation contributing to the genesis of approximately $2 \%$ of all invasive cutaneous melanoma in that country. ${ }^{7}$ In Europe, G101W occurs as a founder mutation in France, Italy and Spain..$^{5}$ A number of common mutations are shared between Australia and the UK, including M53I, IVS2-105A/G, R24P and L32P, reflecting a shared ancestry from British colonisation of Australia in the late 18th century. ${ }^{5}$ Differences in mutation penetrance between regions likely reflect a combination of genetics and environment associated factors, where family members are predicted to share the same ultraviolet radiation (UVR) exposures as well as a number of other heritable genetic modifiers. ${ }^{1}$ Several independent features have been associated with positive $C D K N 2 A$ mutation status, including multiple primary melanomas, high number of family members with melanoma, Breslow thickness $>0.4 \mathrm{~mm}$ and early age of melanoma onset. ${ }^{8} 9$ Compared with the relatively high penetrance in cohorts of familial melanoma, a much lower lifetime risk has been identified for individuals with CDKN2A mutation in population-based analysis. ${ }^{10}$

Among the high penetrance familial melanoma genes, CDKN2A is unique in that it has also been identified as a low penetrance gene conferring increased risk of melanoma in the general population. Genome-wide association studies (GWAS) have shown that variants located around the CDKN2A locus are associated with cutaneous melanoma, naevus count and tanning ability. $^{2}{ }^{11-13}$ Several independent variants are proposed to contribute to complex association signals in the $C D K N 2 A$ region, and the association with melanoma risk is likely to involve multiple single nucleotide polymorphisms (SNPs). ${ }^{2}$ These SNPs include rs869330 and rs7023329 within the MTAP gene, and rs1101970 in CDKN2B-AS1 (figure 1). ${ }^{2} 14$

The above locus is a naevus associated region, with CDKN2A mutation carriers displaying a higher total naevi number and total naevi density compared with non-carriers. ${ }^{15}$ Phenotypic naevus differences have also been observed, with mutation carriers demonstrating significantly more clinically atypical naevi (figure 2). ${ }^{15}$ An atypical naevus has been defined as having one or more of the following clinically observed features: size $>5 \mathrm{~mm}$ in diameter, border or contour irregularity, colour asymmetry or multiple colours, and diffusion of pigment. Some CDKN2A coding region mutation carriers have a clinical phenotype consistent with atypical naevus syndrome, historically also sometimes referred to as dysplastic naevus syndrome, however the variability of phenotypic expression means that not all carriers have atypical naevi. ${ }^{15}$

\section{Cyclin-dependent kinase 4}

Germ line mutations in CDK4 on chromosome 12q14 impact the same pathway as CDKN2A mutations, and the oncogenic effects of $C D K 4$ mutations are primarily via the control of cell cycling in the G1 phase. ${ }^{16}$ Two different mutations have been identified, in codon 24 of exon 2, leading to substitution of arginine with either histidine or cystine. These R24C and R24H mutations lead to CDK4 behaving as a dominant oncoprotein through loss of binding to $\mathrm{p} 16$, its negative regulator. ${ }^{16}$ Thus far, a total of 18 families with CDK4 mutations have been identified worldwide. The R24C variant has been found in six families, from France, Italy, the UK and the USA. ${ }^{16}$ The R24H variant has been found in the other 11 families, comprising
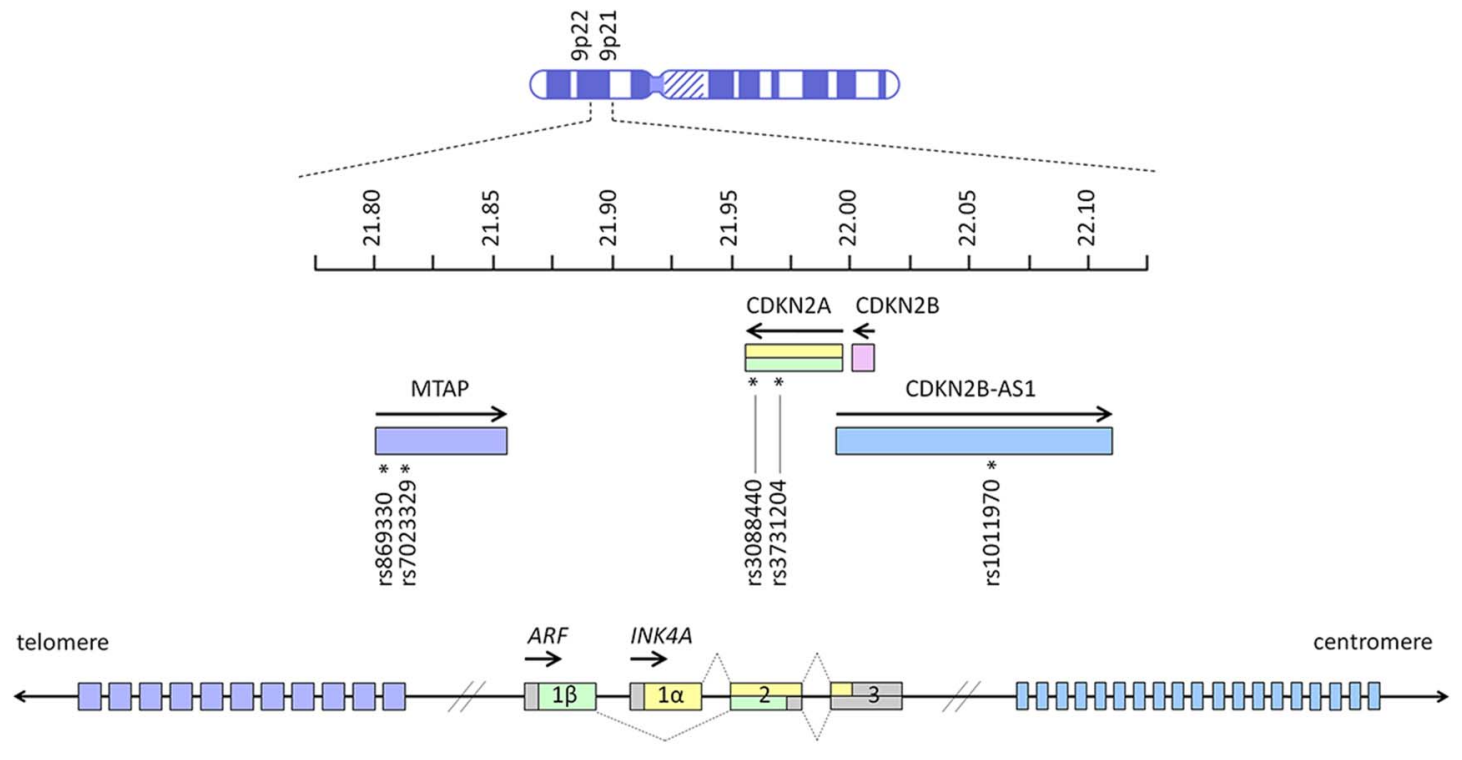

MTAP

CDKN2A

CDKN2B-AS1

Figure 1 Key melanoma-associated single nucleotide polymorphisms on chromosome 9p21 and 9p22 in MTAP (rs869330 at position 21804617, and rs7023329 at position 21816528), CDKN2A (rs3088440 at position 21968159, and rs3731204 at position 21984661) and CDKN2B-AS1 (rs1011970 at position 22062134). ${ }^{2}{ }^{14}$ Arrows indicate the direction in which genes are transcribed. Units next to the chromosome ideogram indicate megabase position of each gene from the terminus of the short arm of chromosome 9. Exons (open boxes) of CDKN2A are numbered, and dotted lines show how alternative splicing generates the alternate reading frame (ARF) and INK4A gene products. 


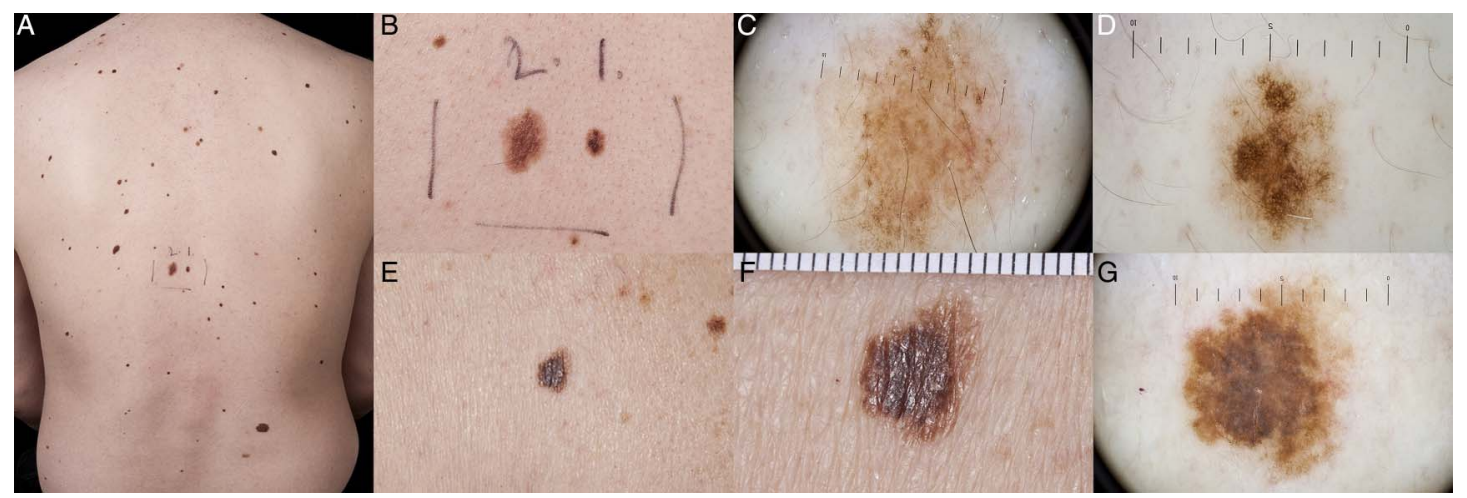

Figure 2 Atypical naevi showing the hallmarks of large size, border or contour irregularity, colour asymmetry or multiple colours, and diffusion of pigment. (A) many atypical naevi on the back; (B) close-up view of centre back naevi seen in A, showing highly irregular contour and colour variation; (C) dermoscopy of left naevus marked ' 2 ' in (A and B), demonstrating peripheral reticular distribution of pigment relatively homogeneously associated with some centrally distributed globules and pigment reinforcement. Overall the lesion is relatively symmetrical; (D) dermoscopy of right naevus marked ' 1 ' in (A and B) showing atypical reticular distribution of pigment with asymmetry in the vertical axis. Relative enlargement of pigment network in focal areas is more central with some radial streaming. Overall the lesion is relatively homogeneous in colour and does not have any blue/white veiling, regression or other hallmarks of melanoma; $(E)$ an atypical naevus of large size, asymmetry, irregular pigmentation and contour; (F) close-up view of naevus seen in ( $E$ and $G$ ) dermoscopy of naevus seen in ( $E$ and $F$ ), showing predominantly reticular distribution of pigment with some areas of amorphous pigment. Asymmetry in the vertical axis, heterogeneous distribution of pigment and irregular borders. Multiple brown/grey dots centrally and symmetrically distributed. No blue/white veil, no regression or other hallmark of melanoma (diagnosis to be interpreted in the context of other lesions on the same patient).

three Latvian families, two French families, and one family each from Australia, Denmark, Greece, Italy, Norway and the UK. ${ }^{16-19}$ In an analysis of 17 families, median age at first melanoma diagnosis was 39 years, and the lifetime mutation penetrance based on the available data was estimated at $74 \% .{ }^{16}$ The low frequency of CDK4 mutations means that very large population studies are required to accurately assess the contribution of CDK4 mutations to the overall burden of familial melanoma and the penetrance of cutaneous melanoma in the context of these mutations.

\section{BRCA1-associated protein-1}

Germ line inactivating mutations in BRCA1-associated protein-1 (BAP1), a tumour suppressor gene on chromosome $3 \mathrm{p} 21$, were initially identified in two distinct syndromes. Testa et al ${ }^{20}$ identified one as characterised by familial aggregation of mesothelioma and uveal melanoma, and Wiesner et $a l^{21}$ concurrently described the other as characterised by multiple morphologically distinct cutaneous melanocytic neoplasms and uveal melanoma. The familial aggregation of cancers associated with a proposed BAP1 syndrome has subsequently been expanded to include cutaneous melanoma, and additional neoplasms are increasingly being linked to BAP1 germ line mutations, including meningioma, cholangiocarcinoma, renal cell carcinoma (RCC) and basal cell carcinoma. ${ }^{22-28}$ The diversity of cancers suggests that the inactivating mutation is variably penetrant for different tumour types, and possibly that mutations in BAP1 depend on other unidentified genetic modifiers for a cancer phenotype to be expressed. The first recurrent BAP1 mutation has recently been reported in three families from two continents, with one family carrying a likely independent mutation based on founder haplotype analysis. ${ }^{28}$ A clustering of uveal and cutaneous melanoma in these families, and the presence of only one mesothelioma case, supports the hypothesis that specific BAP1 variants predispose to certain subsets of cancers. ${ }^{28}$

A cutaneous phenotypic feature for BAP1 germ line mutations has been proposed by the presence of multiple $0.2-1.0 \mathrm{~cm}$ pink to tan papules and nodules, termed 'melanocytic BAP1-mutated atypical intradermal tumours' (MBAITs), or alternatively, 'BAPomas'. ${ }^{21} 29-31$ These lesions are similar but histopathologically distinct from atypical Spitz tumours, lacking characteristic Spitz naevi features, and are also phenotypically distinct from

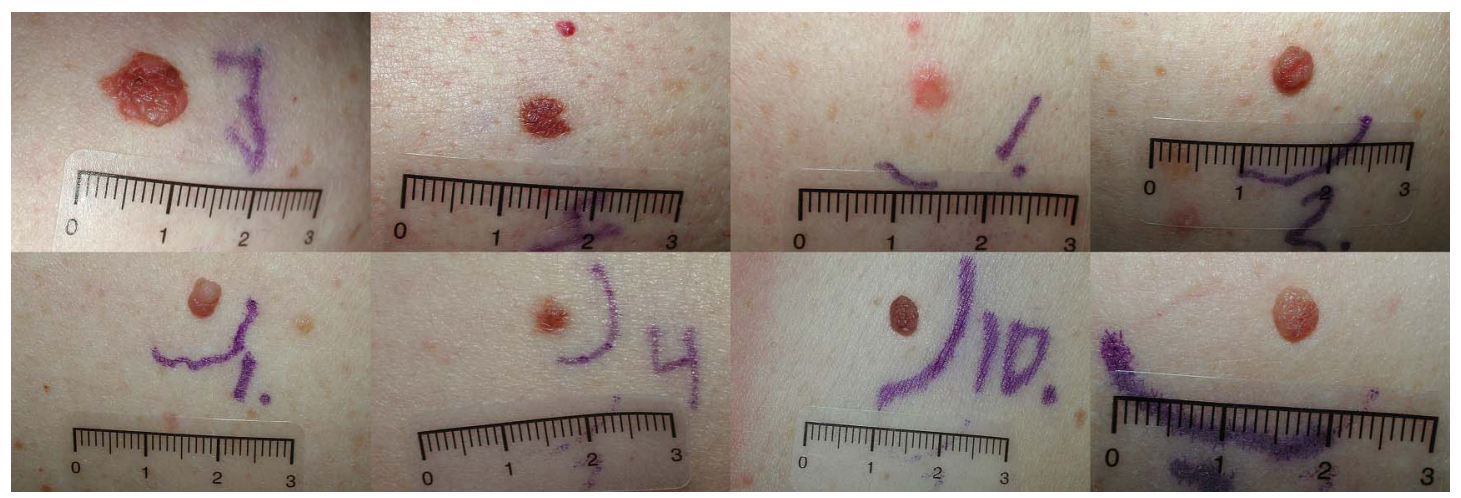

Figure 3 Examples of melanocytic BAP1-mutated atypical intradermal tumours (MBAITs)/BAPomas, demonstrating pink to tan papules and nodules, usually symmetrical in shape and of fairly uniform colour, which contrasts with the phenotype of atypical naevi (figure 2), often seen in CDKN2A mutation carriers. 
naevi seen in carriers of mutations in other melanoma predisposition genes such as CDKN2A (figures 2 and 3). ${ }^{31}$ As these lesions typically occur at a younger age than other cancers, accurate identification could alert to the possibility of BAP1 mutation and prompt amplified cancer surveillance. Although the MBAITs associated with BAP1 mutations were initially reported not to progress to cutaneous melanoma, atypical features of faint orange-red pigment, red papule morphology and halo formation have been described in cutaneous melanomas of individuals in BAP1 mutation positive families. ${ }^{23} 2432$ The features may represent an overlap between the phenotype and cutaneous melanoma, either through transformation of an existing MBAIT, or de novo melanoma development with a phenotype influenced by the specific BAP1 cancer pathway. Of 21 presently reported families affected by BAP1 mutations, 16 families had at least one individual affected by cutaneous melanoma, confirming the place of melanoma in the BAP1 syndrome. ${ }^{20} 22-2527-$ 29 31-35 BAP1 functional inactivation is also proposed to contribute to a small proportion of sporadic cutaneous melanoma, with an absence of BAP1 expression on immunohistochemistry staining described in approximately $5 \%$ of tumours. ${ }^{36}$ Therefore, in the context of familial aggregation of cutaneous melanoma, a tumour with somatic loss of $3 p$ and/or the loss of BAP1 protein expression may suggest screening for a BAP1 germ line mutation is warranted.

\section{Protection of telomeres 1}

Protection of telomeres 1 (POT1) contributes to the sixcomponent protein complex of shelterin, which protects telomeres by preventing them from being mistakenly recognised as deleterious DNA breaks, regulating telomere region DNA replication, as well as telomerase recruitment and activity. ${ }^{37}$
Two recent studies have identified nine highly penetrant germ line mutations in the POT1 gene, the majority of which affect oligonucleotide/oligosaccharide-binding (OB) fold domains, which are essential for the binding of POT1 to telomeric single stranded DNA. ${ }^{37-39}$

POT1 variants appear to be highly penetrant, with one study of melanoma families from the UK, the Netherlands and Australia observing that all nine carriers developed melanoma, in addition to some individuals developing breast and small cell lung cancer. ${ }^{38}$ Melanoma associated POT1 mutations include a p.Tyr89Cys variant of the $\mathrm{N}$-terminal OB domain in a five-case family, and a splice-acceptor variant between exons 17 and 18 in a six-case family. ${ }^{38}$ Two further OB fold domain mutations, p.Gln94Glu and p.Arg273Leu, were each found in a case from different families. ${ }^{38}$

A rare novel missense variant in the OB2 domain, $p$. Ser270Asn, was detected in all 11 cases and obligate carriers from four Italian families, with the same variant also identified in one of two affected individuals in a bilineal Italian family. ${ }^{39}$ Although all five families were apparently unrelated, the haplotype of the POT1 region was shared by all carriers, suggesting a common ancestor approximately 10 generations ago as the source of the founder mutation. ${ }^{39}$ Two further POT1 variants, p.Gln623His and p.Arg137His, were identified in another two Italian families. ${ }^{39}$ In both studies, telomeres of POT1 mutation carriers were relatively long, which has previously been identified as a risk factor for melanoma. ${ }^{40}$

\section{Adrenocortical dysplasia protein homolog/telomeric repeat binding factor 2 interacting protein}

Recently, mutations in other shelterin complex genes have been found to predispose to melanoma (figure 4). Mutations in the
Figure 4 High, medium and low penetrance genes and their chromosome band locations. Black text denotes high penetrance genes; blue text denotes medium penetrance genes; red text denotes low penetrance genes.
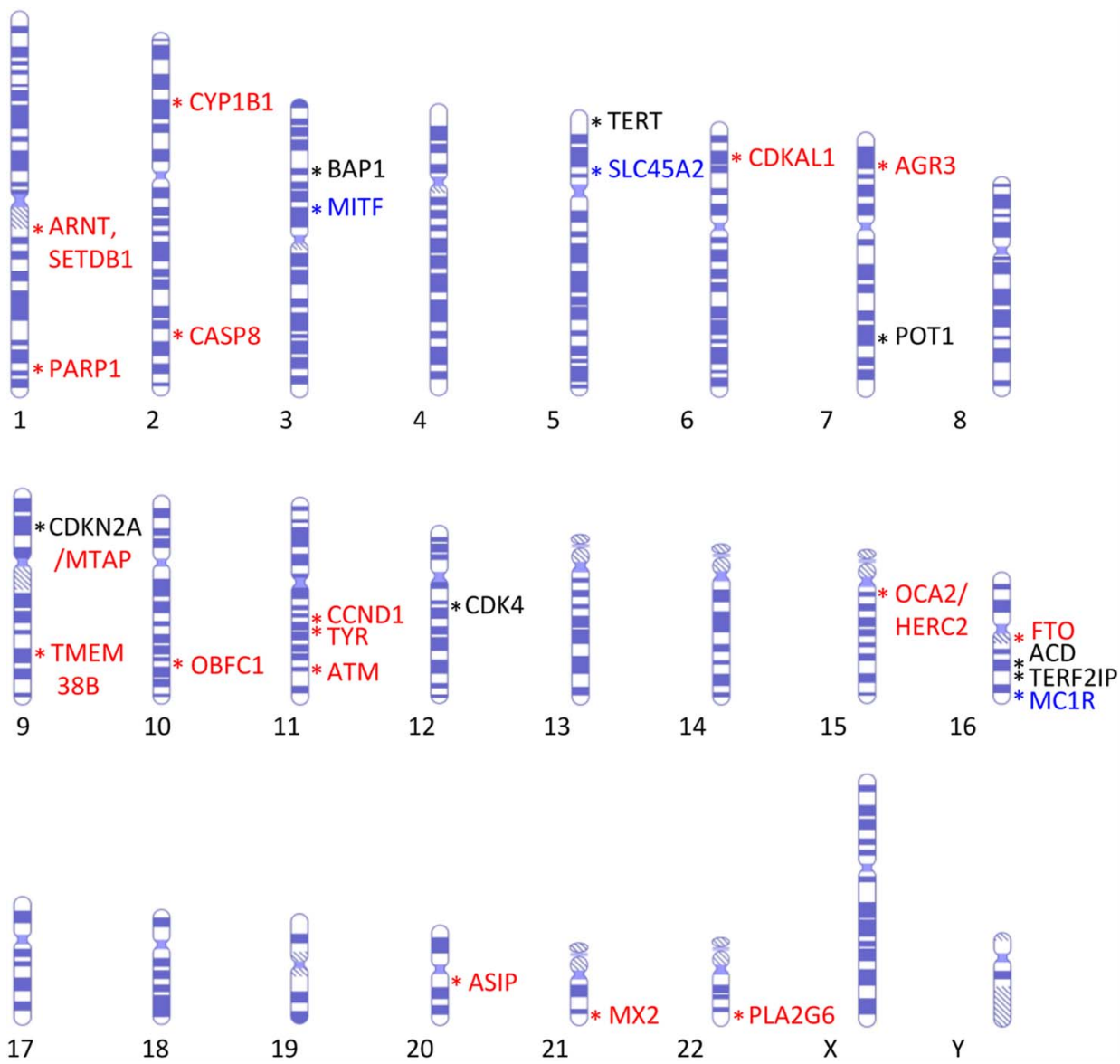
adrenocortical dysplasia protein homolog $(A C D)$ and telomeric repeat binding factor 2 interacting protein (TERF2IP) genes were identified in a study of melanoma families without known genetic aetiology. ${ }^{38} 3941$ In a cohort of melanoma families that were wild type for known predisposition genes, segregating mutations in $A C D$ were found in four families, and another two mutations were identified that did not segregate with all melanoma cases in the families. ${ }^{41} \mathrm{~A}$ nonsense mutation in one Australian family, p.Q320X, segregated in all four cases available for genotyping, and was associated with early age at diagnosis. Another mutation, p.N249S, was identified in an Australian family and a Danish family, with a shared founder haplotype across the $A C D$ locus. In the Australian family, with eight confirmed and four unconfirmed cases of cutaneous melanoma, the mutation segregated in all seven cases available for testing. Of five confirmed and one unconfirmed case in the Danish family, three affected family members were found to be carriers. p. Q320X and p.N249S are within the POT1 binding domain of $A C D$, reflecting the key role of the ACD/POT1 subunit in mediating the elongation of telomeres. ${ }^{41}$

TERF2IP is important in the negative regulation of telomere length, by repressing homology-directed repair. A nonsense mutation and three novel missense variants have been identified. The p.Q191R was associated with onset of melanoma at 15 years and 24 years, and is predicted to disrupt the binding site for TERF2. ${ }^{41}$ This loss is proposed to prevent TERF2IP contributing to the shelterin complex. A case-control analysis of the $A C D$ and TERF2IP mutations in sporadic melanoma cases did not identify any carriers, indicating that rare mutations are likely to be significant only in a familial context. ${ }^{41}$

\section{Telomerase RT}

Progressive shortening of telomeres with each cell division is a characteristic of normal aging, and may be hastened by exposure to harmful environmental risks such as UVR. Maintenance of telomere length is a function of telomerase, and altered telomerase regulation contributes to the limitless replicative potential of cancer cells. Telomerase RT (TERT) encodes a catalytic subunit of telomerase, and somatic TERT promoter mutations have been identified in a variety of cancers, including melanoma. ${ }^{42}$ TERT has also recently been implicated in familial melanoma following high-throughput sequencing of four affected and four nonaffected individuals in a 14-case German family. ${ }^{43}$ After the region was first identified by multipoint linkage analysis, sequencing of all genes in the region revealed several novel variants, including a $T>G$ variant in the TERT promoter. $^{43}$ This germ line mutation was found in all four affected individuals, as well as one unaffected member who was only 36 years old and had multiple naevi. ${ }^{43}$ Two affected individuals developed melanoma at age 20 years and age 30 years, in addition to other cancers, suggesting that this mutation is a rare but highly penetrant melanoma risk mutation. Screening of 168 cell lines from sporadic metastatic melanoma did not find other occurrences of this novel germ line variant, although somatic recurrent UVR-signature mutations elsewhere in the TERT promoter were present in 125 of the cell lines. ${ }^{43}$

\section{MEDIUM PENETRANCE GENES}

The relatively low frequency of high penetrance mutations suggests that a multitude of alternative germ line mutations could help explain melanoma predisposition. Medium and low penetrance alleles are more prevalent in the general population, but singularly, they are unlikely to be enough to drive oncogenesis. ${ }^{44}$ However, the complex interplay of several of these alleles may combine to raise the level of personal melanoma risk above a critical threshold. In this regard, a component of polygenic heritability has been demonstrated to underlie all sporadic cancers. ${ }^{44}$ To date, three medium penetrance genes (ie, those with variants that have ORs of disease association of between 2 and 5) predisposing to melanoma have been identified. Interestingly, all three are involved in natural variation in pigmentation (summarised below).

\section{Melanocortin 1 receptor gene}

The melanocortin 1 receptor gene (MC1R) encodes the G-protein coupled receptor MC1R, which binds $\alpha$-melanocyte stimulating hormone $(\alpha-\mathrm{MSH}){ }^{45}$ Binding of the ligand normally activates adenylate cyclase, which then increases intracellular levels of cyclic AMP (cAMP). Raised cAMP triggers a subsequent cascade via downstream microphthalmia-associated transcription factor (MITF) and tyrosinase to stimulate melanocyte proliferation, dendricity, and eumelanin pigment synthesis (figure 5). ${ }^{45}$ The increase of photoprotective black/brown eumelanin pigments decreases the relative amount of red/yellow pheomelanins, which are poorly protective against UVR. The type and quantity of pigment determines phenotypic expression of skin and hair colour, as well as skin sensitivity to UVR and tanning response. A number of variant $M C 1 R$ alleles associated with reduced cell surface receptor expression have been identified. This situation reduces binding of $\alpha-\mathrm{MSH}$, and subsequently lower cAMP levels result in less eumelanin and a greater proportion of pheomelanins. ${ }^{4-47}$

$M C 1 R$ is highly polymorphic and a link has been established between particular alleles and a red hair colour (RHC) phenotype. Variants most strongly associated with the RHC phenotype are termed $R$ alleles, and the consequently reduced or nonfunctional cell surface receptors and increased pheomelanin causes the phenotypic traits of RHC, fair skin, freckling and inability to $\tan .{ }^{45}$ Other MC1R variants that are more weakly associated with RHC and have less penetrant impact on the cell receptors are designated $r$ alleles. RHC associated MC1R variants are typically inherited in an autosomal recessive pattern. ${ }^{45}$ Variants may be inherited in a heterozygous $+/ R$ or $+/ r$ pattern, or a homozygous $R / R$ or $r / r$ state. Although RHC is generally a recessive trait, increases in the percentage of individuals with fair skin, blonde hair and red hair reflect in vitro studies of a dominant negative effect of $M C 1 R$ variant receptors on co-inherited wild type alleles. ${ }^{45}$ Variants associated with melanoma include the R alleles D84E, R142H, R151C, R160W and $\mathrm{D} 294 \mathrm{H}$, (with ORs of 1.85-2.90) and the $\mathrm{r}$ alleles V60L, V92M, I155T, R163Q and T314T (with ORs of 1.37$2.61){ }^{48} 49$ A French case-control study recently identified 69 rare MC1R polymorphisms, including 25 novel melanoma predisposition variants. ${ }^{48}$ Just over half of the identified alleles were predicted to have a functional impact ( $D$ variants).$^{48}$ Of the novel alleles, $14 \mathrm{D}$ variants were exceedingly rare, each associated with only a single case in the melanoma cohort. Several others were identified in the control group. ${ }^{48}$

A pooled analysis with a large sample size from 17 casecontrol studies found that individuals carrying a single $M C 1 R$ variant had an almost $40 \%$ increased risk of melanoma compared with homozygous wild type controls, and that the risk attributable to any $M C 1 R$ variant was $28 \%{ }^{49}$ For carriers of two or more MC1R variant alleles, the risk of cutaneous melanoma was more than double the risk found for wild type controls. ${ }^{49}$ Interestingly, for individuals with the RHC phenotype, presence of $M C 1 R$ variants alone was insufficient to independently predict melanoma risk. ${ }^{49}$ This could possibly reflect the 


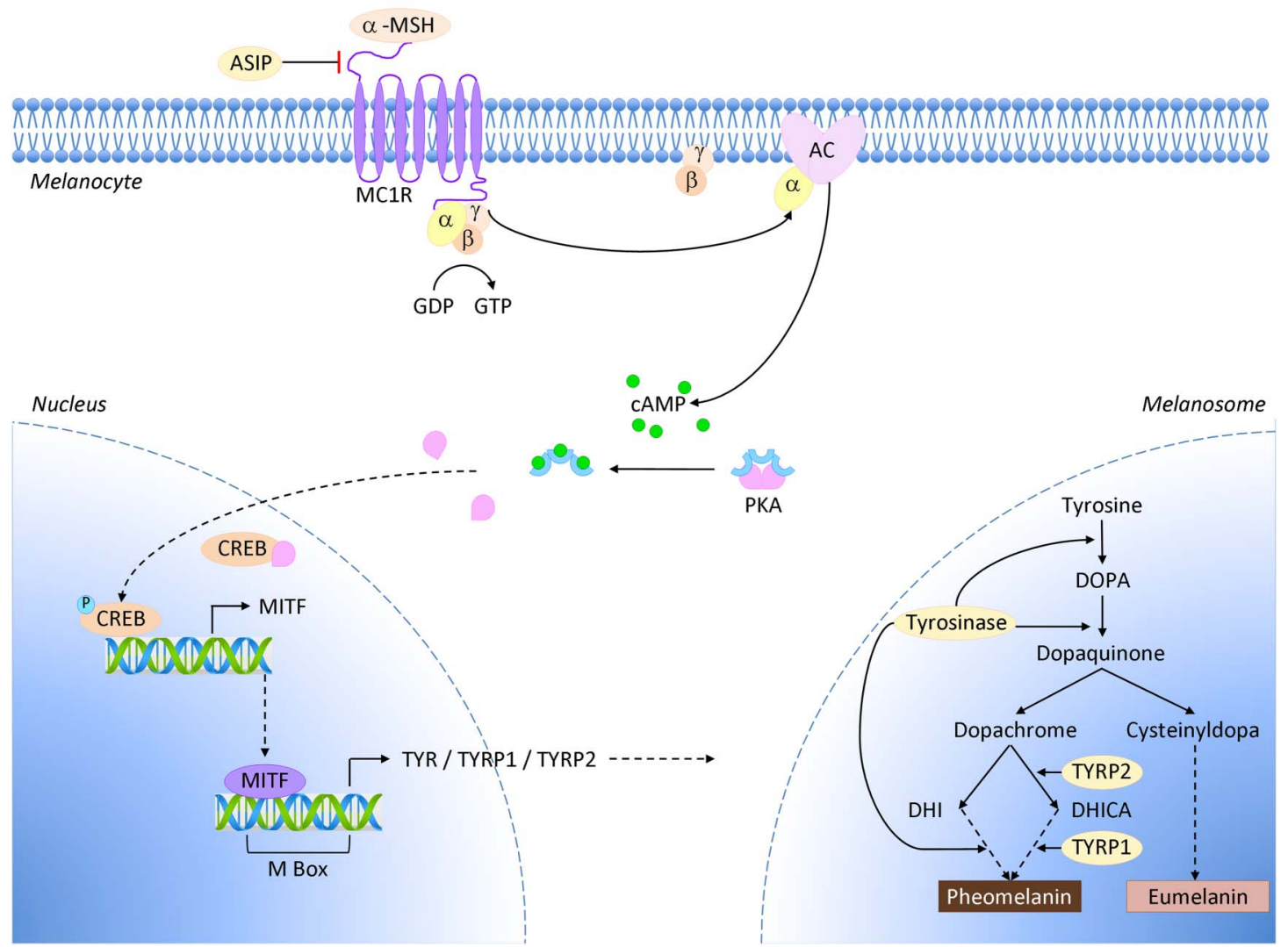

Figure $5 \mathrm{MC1R}$ and the pigment synthesis pathway. Binding of $\alpha$-melanocyte stimulating hormone ( $\alpha$-MSH) to its cognate receptor MC1R on the surface of a melanocyte triggers cyclic AMP (CAMP) production via adenylate cyclase (AC). This activates the CREB and MITF transcription factors, causing an increase in expression of several components of the melanin synthesis pathway, and leads to a switch in pigment production from pheomelanin to eumelanin in melanosomes.

significant role of environment and UVR in modulating risk for RHC variant carriers.

The analysis also revealed an association between MC1R variants and melanoma for Caucasian patients with darkly pigmented skin. ${ }^{49}$ Notably, the MC1R variant/melanoma association has been reported as stronger for photoprotective phenotypes. ${ }^{49} 50$ This may reflect the putative role of $M C 1 R$ in non-pigment pathways, including activation of nucleotide excision repair and other DNA repair mechanisms in response to UVR damage. ${ }^{51-53}$ For variant alleles, a compromised UVR response has been attributed to a diminished $\alpha-\mathrm{MSH}$ mediated oxidative stress response and reduced effects on target DNA damage response genes. ${ }^{53}$ This link to DNA repair helps explain the role of $M C 1 R$ in melanoma susceptibility, suggesting that variant alleles may use either pigment or non-pigment pathways to cause melanoma. The non-pigment pathways are particularly relevant for variants that are associated with melanoma but not with the RHC phenotype. ${ }^{49}$

\section{Microphthalmia-associated transcription factor}

The MITF gene encodes the transcription factor MITF, and is a key regulator of pigment cells, including the development and differentiation of melanocytes. A recently identified recurrent germ line mutation, MITF p.E318K, is responsible for the substitution of glutamic acid at position 318 with lysine. ${ }^{54} 55$ The lysine residue at the site changes the binding affinity for a small-ubiquitin-like modifier (SUMO) protein, and subsequently decreases SUMOylation. ${ }^{54}$ SUMO directed post-translational modification typically impacts transcriptional regulators to inhibit transcription, and thus reduced SUMOylation effectively removes the brakes from MITF action on downstream targets. ${ }^{56}$ Comparison of expression profiles for MITF regulated targets identified 37 genes, with 17 showing modest differences in expression between wild type and p.E318K isoforms. ${ }^{55}$ This difference may indicate that variant MITF mutations have particular transcriptional affinity for specific sets of target genes. Although the precise molecular mechanisms have yet to be fully elucidated, it is apparent that MITF p.E318K acts as a gain of function mutation predisposing to familial melanoma. Carriers of the p.E318K variant have been identified as having a significantly higher risk of developing melanoma (ORs of 2.09-2.19), and the p.E318K mutation has been shown to cosegregate with melanoma in multiple families. ${ }^{545}$ Cosegregation was observed in some but not all family members, implying that it is a medium-penetrance melanoma variant, similar to $M C 1 R .^{55}$ From population analysis of controls, few mutations were detected, therefore denoting MITF p.E318K as a rare population variant. ${ }^{55} 5758$ The p.E318K mutation has also been linked with a particular phenotype, comprising non-blue eye colour, increased number of naevi and multiple primary melanomas. 54555758

\section{Solute carrier family 45 , member 2}

In contrast to MC1R and MITF, solute carrier family 45, member 2 (SLC45A2) variants are associated with darker skin colour, and appear strongly protective against melanoma. The gene product functions as a membrane-associated transporter protein, and is thought to influence pigmentation via the processing and trafficking of melanosomal proteins such as 
tyrosinase. ${ }^{59} 60$ The ancestral variant $374 \mathrm{~L}$ of rs16891982 has been associated with olive and dark skin, and confers a protective effect against melanoma, even for individuals with a fair phenotype (ORs of 2.37-5.50). ${ }^{59} 6162$ This variant is more common in individuals from southern Europe and the Mediterranean region, and there is a decreasing gradient of allele frequency from the south to the north of Europe. ${ }^{60} 63$

\section{LOW PENETRANCE GENES}

In addition to two of the known medium penetrance genes $M C 1 R$ and SLC45A2, 18 other low penetrance risk loci have been associated with melanoma through GWAS (table 1). ${ }^{64}$ Agouti signalling protein (ASIP), tyrosinase (TYR), tyrosinase-related protein 1 (TYRP1) and oculocutaneous albinism type II (OCA2) are involved in pigmentation. ${ }^{2} 606165$ ASIP encodes for an antagonist of $\alpha-\mathrm{MSH}$, which competitively binds to $\mathrm{MC} 1 \mathrm{R}$, thereby preventing MC1R-mediated stimulation of eumelanin synthesis (figure 5). ASIP has been variably associated with melanoma. ${ }^{2}$ Similar to MC1R RHC variants, melanoma-associated ASIP SNPs have been linked to red hair and skin freckling. ${ }^{66}$ TYR impacts eye colour and tanning response, where activity of the enzyme tyrosinase influences the ratio of eumelanin to pheomelanin, and thus TYR alterations can contribute to a fair skin phenotype (figure 5). ${ }^{66}$ TYR SNPs associated with blue eye colour and skin sun sensitivity have been significantly associated with melanoma, as have SNPs in TYRP1. ${ }^{66}$ TYRP1 stabilises the protein encoded by TYR, and therefore mutations in this gene can also affect tanning response. ${ }^{66}$ Further to known phenotypic associations with melanoma, increased risk has been reported for pigment related SNPs in the HERC2/OCA2 region on chromosome $15 \mathrm{q} 13.1 .^{67}$ The two SNPs most significantly associated with melanoma risk are rs1129038 and rs12913832, the latter being a key determinant of human blue-brown eye colour. ${ }^{67} 68$ PLA2G6 is associated with pigmentation and naevi, while CASP8, TERT, AGR3, $M T A P / C D K N 2 A$ and FTO are associated with variation in naevus density. ${ }^{14} 616365-67 \quad 69-78$ In addition to its role in naevus count, TERT is also associated with telomere length, as is OBFC1. ${ }^{73}$ Two loci (PARP1, ATM) are associated with DNA repair, and two others are linked to methylthiolation of tRNA and regulation of cell cycle progression (CDKAL1 and CCND1, respectively). ${ }^{65} \quad 73 \quad 7980$ Four other loci: ARNT/SETDB1, CYP1B1, MX2 and TMEM38B/RAD23B, are associated with melanoma but via uncertain mechanisms. ${ }^{65} 7379$

\section{GENETIC MODIFIERS AND INTERACTIONS}

Overall risk in familial melanoma is modified by the pooled contribution of many factors, including other genes, phenotypical characteristics and the environment. The addition of modifiers or interactions can influence the penetrance of a certain allele, and contribute to increased, or decreased, melanoma susceptibility.

\section{Gene-gene}

Epistasis is a gene-gene interaction, where the effect of a particular gene depends on the presence of another modifier gene. Epistasis can also be linked to multiple genes, where a certain genetic background may be essential for subsequent gene expression. ${ }^{81}$ A number of epistatic mutations likely contribute to the polygenic inheritance of melanoma.

Further to its contribution as an independent risk gene for melanoma, $M C 1 R$ variants act as genetic modifiers by increasing the penetrance of CDKN2A mutations. A recent meta-analysis showed that melanoma risk doubled for patients with mutations in $C D K N 2 A$ and $M C 1 R$ compared with mutated CDKN2A alone, and that carriers of multiple $M C 1 R$ variants were even more likely to develop melanoma. ${ }^{3}$ For potential interactions of $M C 1 R$ with other genes located near CDKN2A, all 10 recently identified candidate polymorphisms on chromosome 9p21 did not show any significant association on interaction analysis. ${ }^{11}$

Telomere length has been also investigated in relation to CDKN2A status, following previous associations between

Table 1 Melanoma loci identified through GWAS

\begin{tabular}{|c|c|c|c|c|c|c|}
\hline Gene & Chromosome band & Regional peak & OR & Pigmentation & Naevi & References \\
\hline$A R N T$, SETDB1 & $1 q 21$ & rs12410869 & 0.88 & No & No & 79 \\
\hline PARP1 & $1 q 42.12$ & rs1858550 & 0.87 & No & No & 79,80 \\
\hline CYP1B1 & $2 \mathrm{p} 22.2$ & rs6750047 & 0.92 & No & No & 73 \\
\hline CASP8 & $2 q 33.1$ & rs7582362 & 0.89 & No & Weak/trend & 65 \\
\hline TERT & $5 p 15.33$ & rs380286 & 1.16 & No & Yes & $65,70,77$ \\
\hline SLC45A2 & 5p13.3-13.2 & rs250417 & 2.44 & Yes, strong & No & $61,63,65,70,72$ \\
\hline CDKAL1 & $6 p 22.3$ & rs6914598 & 1.11 & No & No & 73 \\
\hline AGR3 & $7 p 21.1$ & rs1636744 & 1.11 & No & Weak/trend & 73 \\
\hline MTAP/CDKN2A & $9 p 21.3$ & rs7852450 & 0.81 & No & Weak/trend & $14,65,70,76$ \\
\hline intergenic (TMEM38B) & $9 q 31.2$ & rs10739221 & 0.89 & No & No & 73 \\
\hline OBFC1 & $10 q 24.33$ & rs2995264 & 0.87 & No & No & 73 \\
\hline CCND1 & $11 q 13.3$ & rs498136 & 0.89 & No & No & 65 \\
\hline TYR & $11 q 14.3$ & rs1393350 & 1.22 & Yes, strong & No & $14,66,69,70$ \\
\hline ATM & $11 q 22.3$ & rs73008229 & 0.83 & No & No & 65 \\
\hline OCA2/HERC2 & $15 q 12-13.1$ & rs4778138 & 0.84 & Yes, strong & No & $63,67,71-73$ \\
\hline FTO & $16 q 12.2$ & rs12596638 & 1.15 & No & Yes & 78 \\
\hline MC1R & $16 q 24.3$ & rs75570604 & 1.82 & Yes, strong & No & $14,68,70$ \\
\hline ASIP & $20 q 11.22$ & rs6059655 & 1.42 & Yes, strong & No & $14,66,69,70,74,75$ \\
\hline $\mathrm{M} \times 2$ & $21 q 22.3$ & rs408825 & 1.15 & No & No & 65 \\
\hline PLA2G6 & $22 q 13.1$ & rs2092180 & 0.89 & Yes & Yes & $14,61,65,76$ \\
\hline
\end{tabular}

GWAS, genome-wide association studies. 
cutaneous melanoma and longer telomeres. In contrast to noncarriers, the study failed to show a link between telomere length and melanoma for carriers of CDKN2A mutations, either suggesting a divergent melanoma pathway in these individuals, or more likely, insufficient power to detect an association. ${ }^{40}$

Interaction between the MITF p.E318K allele and $M C 1 R$ RHC variants has been variably reported, and there does not appear to be an interaction in the majority of patients. ${ }^{58} 82$ However, one patient in an Australian cohort with a p.E318K allele and MC1R homozygous R/R genotype developed three amelanotic melanomas, suggesting a genetic interaction as the source of this phenotype. ${ }^{58} \mathrm{An}$ analysis of 33 candidate polymorphisms in several pigmentation genes and the vitamin D receptor (VDR) gene identified significant epistatic effects between MC1R and TYR, and SLC45A2 and VDR, among others. $^{12}$

$M C 1 R$ has been proposed to also interact with somatic $B R A F$ p.V600E mutations to drive melanomagenesis, likely by allowing cells to bypass senescence. ${ }^{83}$ In vivo studies have demonstrated that the simultaneous expression of BRAF p.V600E and $M C 1 R$ depletion results in greater melanocyte growth and tumour formation compared with either factor alone. ${ }^{83}$

\section{Gene-phenotype}

Pigmentation traits with less melanin are linked to melanoma via reduced protection against UVR. Phenotypic risk factors for melanoma in the general population include blue or green eyes, fair or red hair, fair skin with increased sun sensitivity and an inability to tan, high numbers of naevi, and atypical naevi. Several genetic variants predisposing to pigment and naevus phenotypes have been identified in the general population, which in turn have been implicated in predisposition to melanoma. ${ }^{45}$

In addition to the effect on DNA repair, the variant MC1R-mediated RHC phenotype of red hair, pale skin, and an inability to tan confers melanoma susceptibility by increased potential for sunburn and UVR damage. ${ }^{45}$ The medium penetrance risk gene MITF has been associated with the phenotypic characteristic of high naevus count. ${ }^{55} 58$ In an Australian study, carriers displayed significantly higher counts of naevi greater than $5 \mathrm{~mm}$, but without distinct dermoscopic naevus signature patterns. ${ }^{58}$ For carriers of the p.E318K mutation, there was an association with non-blue eye colour but no association with other known phenotypic characteristics, including skin colour, hair colour and freckling. ${ }^{55}$

\section{Gene-environment}

The most significant independent environmental risk factor for melanoma is UVR exposure, and a potential interaction between geographical location and $C D K N 2 A$ penetrance has been observed. A large international study of families from three continents found significant variation in mutation penetrance depending on geographical location, likely correlating with associated UVR exposure. ${ }^{1}$ By age 50 years, mutation penetrance reached $0.13,0.50$ and 0.32 in Europe, the USA and Australia, respectively. By age 80 years, it was 0.58 in Europe, 0.76 in the USA and a staggering 0.91 in Australia. ${ }^{1}$ Although these penetrance rates appear to correspond with latitude and hence UVR exposure, it is possible that varying penetrance of different region specific $C D K N 2 A$ variants or co-inheritance of other genetic modifiers could contribute to the differences.

Tobacco smoke has been linked to increased penetrance of $C D K N 2 A$ for pancreatic, upper gastrointestinal and respiratory cancers, and it is hypothesised that it may also affect CDKN2A penetrance for melanoma. ${ }^{4}$

\section{FAMILIAL MELANOMA MUTATIONS AND RISK OF OTHER CANCERS}

Some familial cutaneous melanoma predisposition genes have also been linked to risk of other tumour types, where the incidence of specific cancers occurs within melanoma families at rates greater than expected by chance (table 2 ).

The most extensively documented association is between CDKN2A and pancreatic cancer, although associations have been noted for a range of other cancers. ${ }^{458485}$ A study of carriers of the Swedish p.Arg112dup CDKN2A founder mutation found significantly increased risk of pancreatic cancer, upper digestive (oral cavity, tongue, pharynx, larynx, oesophagus, stomach, liver, gall bladder) cancers and respiratory (bronchi and lung) cancers. $^{4}$ At age 80 years, $53 \%$ of carriers were reported to have at least one of these specific cancers. ${ }^{4}$ Interestingly, the risk of cancer was significantly higher in individuals who had ever smoked, compared with carriers who had never smoked. ${ }^{4}$ Upper gastrointestinal and respiratory tissues

Table 2 Melanoma predisposition genes and associations with other cancers

\begin{tabular}{|c|c|c|c|c|c|}
\hline Gene & $\begin{array}{l}\text { Chromosome } \\
\text { band }\end{array}$ & Modifiers & $\begin{array}{l}\text { Associated non-cutaneous } \\
\text { melanoma cancers }\end{array}$ & Possibly associated cancers* & References \\
\hline CDKN2A & $9 \mathrm{p} 21$ & $\begin{array}{l}\text { MC1R, UVR, } \\
\text { possibly tobacco } \\
\text { smoke }\end{array}$ & Pancreas & $\begin{array}{l}\text { ENT (tongue, oral cavity, pharynx, larynx), upper digestive } \\
\text { (oesophagus, stomach), brain, breast, cervix, gall bladder, thyroid, } \\
\text { leukaemia, liver, lung, lymphoma, renal }\end{array}$ & $5,6,85,86$ \\
\hline CDK4 & $12 q 14$ & - & - & $\begin{array}{l}\text { Breast, cervix, colorectal, lung, lymphoma, pancreas, stomach, } \\
\text { uterine }\end{array}$ & $17-20$ \\
\hline BAP1 & $3 p 21.1$ & - & $\begin{array}{l}\text { RCC, uveal melanoma, } \\
\text { mesothelioma, BCC, } \\
\text { cholangiocarcinoma }\end{array}$ & $\begin{array}{l}\text { Bone, bladder, breast, colorectal, lung adenocarcinoma, } \\
\text { meningioma, neuroendocrine, ovarian, paraganglioma, stomach, } \\
\text { thyroid }\end{array}$ & $21-36$ \\
\hline MITF & $3 p 14.2$ & Possibly MC1R & RCC, pancreas & $\begin{array}{l}\text { Bladder, brain (glioblastoma), breast, colorectal, endometrial, } \\
\text { leukaemia, lung, lymphoma, myeloma, prostate, stomach }\end{array}$ & $55,56,58$ \\
\hline TERT & $5 p 15.33$ & - & - & Bladder, breast, endometrial, lung, ovarian, renal & 43,44 \\
\hline POT1 & $7 q 31.33$ & - & Glioma & Brain, breast, CLL, endometrial, leukaemia, thyroid, SCLC & $39,40,90,91$ \\
\hline$A C D$ & $16 q 22.1$ & - & - & Breast, colorectal, leukaemia, lung, lymphoma & 42 \\
\hline TERF2IP & $16 q 23.1$ & - & - & Breast, cervix, meningioma, ovarian & 42 \\
\hline
\end{tabular}


are particularly sensitive to carcinogens, and exposure to tobacco smoke and other environmental carcinogens may increase the penetrance of $C D K N 2 A$ in these cancers in a similar manner to UVR and melanoma. An international study reported an increased risk of all non-melanoma cancers in first degree relatives of CDKN2A mutation carriers. ${ }^{84}$ For mutation carriers, the lifetime risk of any cancer other than melanoma was estimated at $59 \%$ by age 85 years. ${ }^{84}$

Further to CDKN2A variants and melanoma risk, the $9 \mathrm{p} 21$ locus has been linked to a variety of other cancers. An analysis of eight different GWAS identified several significant SNPs in this region, including some variants associated with multiple cancers. ${ }^{86}$ Of particular note may be the CDKN2A intronic rs3731239 SNP, which was associated with oesophageal squamous cell cancer, gastric cancer and breast cancer. ${ }^{86}$ Although these results to do not directly relate to specific melanoma risk SNPs, it is interesting to consider the potential impact of this region to cancer susceptibility more generally, and as a potential site for other novel cancer predisposition variants.

An association with multiple cancers has also been indicated for POT1. ${ }^{38} 39$ Other cancer types include breast cancer, small cell lung cancer, endometrial cancer and brain tumours, which have been observed in POT1 mutation carriers and their untested family members. There may also be a link with chronic lymphocytic leukaemia (CLL), which has somatic mutations in POT1 at relatively high frequency, the majority of which affect the OB folds, a finding that is in keeping with alterations detected in the recent melanoma studies. ${ }^{38} 398788$ One POT1 mutation carrier had a history of melanoma and CLL, and it is possible that a variant exists that could affect a portion of the OB fold domain that is relevant to the development of melanoma and CLL. ${ }^{38}$

Additionally, POT1 has recently been implicated in the development of glioma. ${ }^{89}$ Three novel protein-changing variants have been described, each found in one family with a high case density of glioma. In one family with six carriers and one obligate carrier of p.G95C, three individuals developed glioma at young ages. ${ }^{89}$ Of six carriers in a family with a p.E450X mutation, two were affected by glioma. ${ }^{89}$

Glioma has previously been tentatively associated with melanoma following the observation of more melanoma cases than expected in glioma families. ${ }^{90}$ Although the underlying basis for susceptibility is uncertain, analysis of potential glioma susceptibility loci by GWAS has identified variants in chromosome $9 \mathrm{p} 21$ near CDKN2A and CDKN2B. ${ }^{91}{ }^{92}$ The glioma candidates are not in the same linkage disequilibrium block as the CDKN2A melanoma gene, but it suggests the possibility that this region may account for shared predisposition to both cancers.

More cancers than expected have also been found in families carrying ACD and TERF2IP mutations, which like POT1, affect the shelterin complex. Although the numbers are too few to be statistically significant, additional cancers in carriers with melanoma include lung, breast, bowel and haematological malignancies, suggesting a possible $A C D / T E R F 2 I P$ associated spectrum of cancers. $^{41}$

Somatic TERT promoter mutations have been found in a wide range of different cancer types, and the occurrence of multiple additional cancers in individuals affected by a novel germ line promoter mutation suggests that these other cancers could be due to dysregulation of TERT. ${ }^{42}{ }^{43}$ One individual was diagnosed with endometrial cancer at age 27 years and melanoma at age 30 years. A second affected family member developed melanoma at age 20 years, then subsequently had ovarian cancer, RCC, bladder cancer, mammary carcinoma and bronchial carcinoma before her death at age 50 years. ${ }^{43}$ It has been suggested that the nucleotide sequence change in the germ line variant creates a binding motif similar to the one already used by the ternary complex factor Elk1, which has been demonstrated as a transcriptional regulator in breast, cervical and endometrial cancers. ${ }^{43} 93-95$ Although a tenuous link, this could help explain gender related differences as well as the presence of endometrial, ovarian and breast cancers.

A bidirectional association has been established between melanoma and RCC for sporadic cases, and a number of familial melanoma studies have also noted an over-representation of this cancer. ${ }^{96}$ RCC and pancreatic cancer have been linked to the p. E318K mutation in MITF, and a potential connection between melanoma and lymphoma has been noted. ${ }^{54} 5557$ Mutation p. E318K upregulates hypoxia inducible factor, which has been identified as the downstream target of other known RCC predisposition genes. ${ }^{54}$ BAP1 has also recently been associated with the development of RCC. In an analysis of 60 French families with BAP1-reminiscent cancer clustering, RCC-affected individuals were identified in 6 out of 11 families with germ line BAP1 mutations. ${ }^{26} \mathrm{~A}$ novel variant has been detected in one American family with multiple cases of RCC but no other cancers, suggesting that germ line BAP1 mutations may rarely predispose solely to RCC. ${ }^{97}$

The high density of cancer in families affected by germ line BAP1 mutations suggests that this gene is a critical regulator of oncogenesis for the tumours identified. ${ }^{30}$ The numerous functional domains of the BAP1 protein present a range of potential sites for mutation. Therefore a number of germ line variants may exist, each possibly contributing to a different collection of cancers. Further to the heterogeneity of BAP1 mutations, it is likely that modifier genes and environmental factors also impact the cancer phenotype in BAP1 families. A BAP1 cancer cluster comprised of cutaneous/ocular melanoma, atypical melanocytic proliferations, and other internal neoplasms such as mesothelioma has been proposed as a particular syndrome. ${ }^{23}$ However, further studies have implicated a range of other cancers as part of a possible BAP1 spectrum. In addition to RCC, possibly associated neoplasms include lung adenocarcinoma, meningioma, paraganglioma, breast cancer, neuroendocrine tumours, gastric cancer and basal cell carcinoma. ${ }^{22} 24252728$ These findings hint at the prospect of many other BAP1 associated cancers as more families are identified.

\section{FAMILIAL CANCER SYNDROMES AND MELANOMA RISK}

A number of other rare autosomal familial cancer syndromes have been described, characterised by the occurrence of multiple cancers including melanoma. These include Li-Fraumeni syndrome, xeroderma pigmentosum, Werner syndrome and familial breast cancer. Li-Fraumeni syndrome is linked to TP53, and germ line mutations are associated with breast cancer, bone and soft tissue sarcomas, brain tumours and adrenocortical carcinomas. ${ }^{9} 99$ The inclusion of melanoma in the syndrome has been controversial, however a handful of melanoma cases have been reported, including one patient with a germ line TP53 mutation who presented with multiple primary cutaneous melanomas. ${ }^{100}$ In contrast, xeroderma pigmentosum is an autosomal recessive condition caused by mutations in one of eight nucleotide excision repair genes, and the DNA repair function they encode is crucial to the cellular response to UVR-induced DNA damage. ${ }^{101}$ Coupled with UVR damage, this failure in DNA repair predisposes to increased sun sensitivity and skin cancers. A 2000-fold and 10000 -fold increase in melanoma and nonmelanoma skin cancers, respectively, has been reported, as well 
as an increase in neural system cancers. ${ }^{101}$ Werner syndrome is also autosomal recessive, and loss of function mutations in the WRN gene lead to premature aging and multiple cancer susceptibilities, with the spectrum comprising thyroid cancer, melanoma, meningioma, sarcomas and leukaemia. ${ }^{102}$ Analysis of tumours other than breast cancer in carriers of BRCA1 or $B R C A 2$ mutations has shown that BRCA2 defects are associated with 2.6-fold and 99.4-fold increased risks of cutaneous and uveal melanoma, respectively, but there is no increase in melanoma risk associated with BRCA1 mutation. ${ }^{103} 104$

\section{CLINICAL IMPLICATIONS AND FUTURE PRACTICE}

The identification of cancer predisposition genes by genetic testing is typically only recommended when the results influence clinical decisions and treatment can be implemented to prevent or improve clinical outcomes. ${ }^{105}$ Genetic testing in melanoma is therefore controversial, due to the relatively low frequency of high penetrance mutations and the contribution of multiple additional factors that modulate melanoma risk. Despite this, heightened surveillance and more regular skin checks could be a useful outcome for a patient with a known susceptibility.

One of the main benefits encountered from genetic testing is that it may prompt useful discussions about melanoma risk, early detection and prevention with multiple family members. The impact of melanoma risk discussion on the effect on future sun safety behaviours has been demonstrated in a group of family members identified for CDKN2A testing. ${ }^{106}$ Two years following genetic testing, individuals sustained improvements in daily sun protection and fewer sunburns, with no diminution after a negative test result. ${ }^{106}$ Although this study is subjective, it highlights the potential positive impact of increasing awareness and education. Counselling may therefore form an opportunistic intervention to motivate preventative behaviours and minimise UVR exposure risk.

With time, it is anticipated that the data pool of presently known variants will expand, which will be particularly important for analysis of rare variants in a wider population. For families with a high cancer burden but no carriers of previously identified predisposition genes, next-generation sequencing will be key to identifying potential novel high penetrance variants and narrow the present knowledge gap. If future studies indicate clinical utility for genetic testing, it is likely that only high penetrance predisposition genes would be prioritised for gene panels dedicated to melanoma risk evaluation. Although the epistatic effect of $M C 1 R$ variants on $C D K N 2 A$ penetration has been noted, it is less likely that low penetrance risk or medium penetrance risk genes would be used as routine screening tests due to the uncertainty of predicting the clinical outcome of disease development. $^{3}$

Progressing from attribution of melanoma risk, future practice in familial melanoma may involve novel susceptibility genes as a basis for development of early detection strategies. The possibility of combining clinical and genetic information for prognostic estimates has been proposed, where a novel logistic regression model of two significant SNPs, histological tumour type and stage at diagnosis had an improved discrimination of 3-year melanoma recurrence compared with histology and stage alone. ${ }^{107}$ A recently published study analysed 2339 SNPs in 14 autosomal genes of the Fanconi anaemia pathway, which is involved in the cross-link repair of DNA. Four SNPs were significantly associated with reduced overall survival and melanoma-specific survival, and combination of these factors with tumour stage and Breslow thickness further refined 5-year predictive ability. ${ }^{108}$
Although the potential for targeted treatments directed at germ line mutations seems unlikely, it may be plausible in the future, particularly for high penetrance genetic variants with germ line and sporadic manifestations.

\section{CONCLUSION}

Overall, the landscape of melanoma risk genes is becoming gradually less mysterious, with the addition of BAP1, POT1, $A C D, T E R F 2 I P$ and TERT to the known high penetrance melanoma risk genes CDKN2A and CDK4. Ongoing studies of recently identified pigmentation genes in a wider population will be highly significant in their independent risk and the additional risk conferred by gene-gene and gene-phenotype interactions. Novel candidate genes are promising, however there likely still remains a great many to be elucidated. The contribution of melanoma risk genes to other cancers is particularly important for families with observed cancer clustering, where novel genes may also predispose to other cancers. In the future, it is plausible that melanoma risk genes could be used for genetic counselling of melanoma as well as the other cancers they influence. The most important outcome of familial melanoma research will be in clinical application, and even without genetic testing, awareness of the hereditary component of melanoma is likely to improve health promotion and advocacy as part of holistic patient care. Future research will continue to validate known risk genes in wider populations, and will also aim to discover novel predisposition genes for the large percentage of families with a high case density but no identified presently known genes. Although routine genetic testing is currently not recommended due to the complex polygenic interplay that influences the clinical picture of melanoma, the potential for predisposition genes to be utilised as screening tools, for prognostic information, and as targets for treatment may be important in future practice.

Acknowledgements NKH is supported by a fellowship from the National Health and Medical Research Council of Australia. The authors are extremely grateful to $\mathrm{Dr}$ Ulrikke Lei, MD, Senior Consultant in Dermatology, Herlev and Gentofte Hospital, Hellerup, Denmark for kindly providing some of the clinical photographs, and to Dr Matthew Law, QIMR Berghofer Medical Research Institute for statistical analysis of low penetrance risk loci.

Contributors Preparation of initial manuscript and figures: JR. Revision and review of all drafts: JR and NKH. Sourcing of clinical photographs: KAWW. Drafting of final versions of the manuscript and final approval of manuscript: JR, NKH and KAWW.

Competing interests None declared.

Provenance and peer review Not commissioned; externally peer reviewed.

\section{REFERENCES}

1 Goldstein AM, Chan M, Harland M, Hayward NK, Demenais F, Bishop DT, Azizi E, Bergman W, Bianchi-Scarra G, Bruno W, Calista D, Albright LA, Chaudru V, Chompret A, Cuellar F, Elder DE, Ghiorzo P, Gillanders EM, Gruis NA, Hansson J, Hogg D, Holland EA, Kanetsky PA, Kefford RF, Landi MT, Lang J, Leachman SA, MacKie RM, Magnusson V, Mann GJ, Bishop JN, Palmer JM, Puig S, Puig-Butille JA, Stark M, Tsao H, Tucker MA, Whitaker L, Yakobson E. Features associated with germline CDKN2A mutations: a GenoMEL study of melanoma-prone families from three continents. J Med Genet 2007;44:99-106.

2 Barrett JH, Taylor JC, Bright C, Harland M, Dunning AM, Akslen LA, Andresen PA, Avril MF, Azizi E, Bianchi Scarra G, Brossard M, Brown KM, Debniak T, Elder DE, Friedman E, Ghiorzo P, Gillanders EM, Gruis NA, Hansson J, Helsing P, Hocevar M, Hoiom V, Ingvar C, Landi MT, Lang J, Lathrop GM, Lubinski J, Mackie RM, Molven A, Novakovic S, Olsson H, Puig S, Puig-Butille JA, van der Stoep N, van Doorn R, van Workum W, Goldstein AM, Kanetsky PA, Pharoah PD, Demenais F, Hayward NK, Newton Bishop JA, Bishop DT, lles MM. Fine mapping of genetic susceptibility loci for melanoma reveals a mixture of single variant and multiple variant regions. Int J Cancer 2014;136:1351-60.

3 Fargnoli MC, Gandini S, Peris K, Maisonneuve P, Raimondi S. MC1R variants increase melanoma risk in families with CDKN2A mutations: a meta-analysis. Eur J Cancer 2010;46:1413-20. 
4 Helgadottir H, Hoiom V, Jonsson G, Tuominen R, Ingvar C, Borg A, Olsson H, Hansson J. High risk of tobacco-related cancers in CDKN2A mutation-positive melanoma families. J Med Genet 2014;51:545-52.

5 Goldstein AM, Chan M, Harland M, Gillanders EM, Hayward NK, Avril MF, Azizi E, Bianchi-Scarra G, Bishop DT, Bressac-de Paillerets B, Bruno W, Calista D, Cannon Albright LA, Demenais F, Elder DE, Ghiorzo P, Gruis NA, Hansson J, Hogg D, Holland EA, Kanetsky PA, Kefford RF, Landi MT, Lang J, Leachman SA, Mackie RM, Magnusson V, Mann GJ, Niendorf K, Newton Bishop J, Palmer JM, Puig S, Puig-Butille JA, de Snoo FA, Stark M, Tsao H, Tucker MA, Whitaker L, Yakobson E. High-risk melanoma susceptibility genes and pancreatic cancer, neural system tumors, and uveal melanoma across GenoMEL. Cancer Res 2006;66:9818-28.

6 de Snoo FA, Bishop DT, Bergman W, van Leeuwen I, van der Drift C, van Nieuwpoort FA, Out-Luiting CJ, Vasen HF, ter Huurne JA, Frants RR, Willemze R, Breuning $\mathrm{MH}$, Gruis NA. Increased risk of cancer other than melanoma in CDKN2A founder mutation (p16-Leiden)-positive melanoma families. Clin Cancer Res 2008;14:7151-7.

7 Goldstein AM, Stacey SN, Olafsson JH, Jonsson GF, Helgason A, Sulem $P_{\text {, }}$ Sigurgeirsson B, Benediktsdottir KR, Thorisdottir K, Ragnarsson R, Kjartansson J, Kostic J, Masson G, Kristjansson K, Gulcher JR, Kong A, Thorsteinsdottir U, Rafnar T, Tucker MA, Stefansson K. CDKN2A mutations and melanoma risk in the Icelandic population. J Med Genet 2008;45:284-9.

8 Pedace L, De Simone P, Castori M, Sperduti I, Silipo V, Eibenschutz L, De Bernardo C, Buccini P, Moscarella E, Panetta C, Ferrari A, Grammatico P, Catricala C. Clinical features predicting identification of CDKN2A mutations in Italian patients with familial cutaneous melanoma. Cancer Epidemiol 2011;35:e116-20.

9 van der Rhee JI, Krijnen P, Gruis NA, de Snoo FA, Vasen HF, Putter H, Kukutsch $N A$, Bergman W. Clinical and histologic characteristics of malignant melanoma in families with a germline mutation in CDKN2A. J Am Acad Dermatol 2011;65:281-8

10 Begg CB, Orlow I, Hummer AJ, Armstrong BK, Kricker A, Marrett LD, Millikan RC, Gruber SB, Anton-Culver H, Zanetti R, Gallagher RP, Dwyer T, Rebbeck TR, Mitra $\mathrm{N}$, Busam K, From L, Berwick M. Lifetime risk of melanoma in CDKN2A mutation carriers in a population-based sample. J Natl Cancer Inst 2005;97:1507-15.

11 Maccioni L, Rachakonda PS, Bermejo JL, Planelles D, Requena C, Hemminki K, Nagore E, Kumar R. Variants at the 9p21 locus and melanoma risk. BMC Cancer 2013;13:325.

12 Kumar R, Smeds J, Berggren P, Straume O, Rozell BL, Akslen LA, Hemminki K. A single nucleotide polymorphism in the $3^{\prime}$ untranslated region of the CDKN2A gene is common in sporadic primary melanomas but mutations in the CDKN2B, CDKN2C, CDK4 and p53 genes are rare. Int J Cancer 2001;95:388-93.

13 Yang XR, Liang X, Pfeiffer RM, Wheeler W, Maeder D, Burdette L, Yeager M, Chanock S, Tucker MA, Goldstein AM. Associations of 9p21 variants with cutaneous malignant melanoma, nevi, and pigmentation phenotypes in melanoma-prone families with and without CDKN2A mutations. Fam Cancer 2010;9:625-33.

14 Bishop DT, Demenais F, lles MM, Harland M, Taylor JC, Corda E, Randerson-Moor J, Aitken JF, Avril MF, Azizi E, Bakker B, Bianchi-Scarra G, Bressac-de Paillerets B, Calista D, Cannon-Albright LA, Chin AWT, Debniak T, Galore-Haskel G, Ghiorzo P, Gut I, Hansson J, Hocevar M, Hoiom V, Hopper JL, Ingvar C, Kanetsky PA, Kefford RF, Landi MT, Lang J, Lubinski J, Mackie R, Malvehy J, Mann GJ, Martin NG, Montgomery GW, van Nieuwpoort FA, Novakovic S, Olsson H, Puig S, Weiss M, van Workum W, Zelenika D, Brown KM, Goldstein AM, Gillanders EM, Boland A, Galan P, Elder DE, Gruis NA, Hayward NK, Lathrop GM, Barrett JH, Bishop JA. Genome-wide association study identifies three loci associated with melanoma risk. Nat Genet 2009;41:920-5.

15 Florell S, Meyer S, Boucher K, Porter-Gill P, Hart M, Erickson J, Cannon Albright LA, Pershing L, Harris R, Samlowski W, Zone J, Leachman S. Longitudinal assessment of the nevus phenotype in a melanoma kindred. J Invest Dermatol 2004; 123:576-82.

16 Puntervoll HE, Yang XR, Vetti HH, Bachmann IM, Avril MF, Benfodda M, Catricala C, Dalle S, Duval-Modeste AB, Ghiorzo P, Grammatico P, Harland M, Hayward NK, Hu HH, Jouary T, Martin-Denavit T, Ozola A, Palmer JM, Pastorino L, Pjanova D, Soufir N, Steine SJ, Stratigos AJ, Thomas L, Tinat J, Tsao H, Veinalde R, Tucker MA, Bressac-de Paillerets B, Newton-Bishop JA, Goldstein AM, Akslen LA, Molven A. Melanoma prone families with CDK4 germline mutation: phenotypic profile and associations with MC1R variants. J Med Genet 2013;50:264-70.

17 Nikolaou V, Kang X, Stratigos A, Gogas H, Latorre MC, Gabree M, Plaka M, Njauw CN, Kypreou K, Mirmigi I, Stefanaki I, Tsao H. Comprehensive mutational analysis of CDKN2A and CDK4 in Greek patients with cutaneous melanoma. Br J Dermatol 2011;165:1219-22.

18 Veinalde R, Ozola A, Azarjana K, Molven A, Akslen LA, Donina S, Proboka G, Cema I, Baginskis A, Pjanova D. Analysis of Latvian familial melanoma patients shows novel variants in the noncoding regions of CDKN2A and that the CDK4 mutation R24H is a founder mutation. Melanoma Res 2013;23:221-6.

19 Wadt KA, Aoude LG, Krogh L, Sunde L, Bojesen A, Gronskov K, Wartacz N, Ek J, Tolstrup-Andersen M, Klarskov-Andersen M, Borg A, Heegaard S, Kiilgaard JF, Hansen TV, Klein K, Jonsson G, Drzewiecki KT, Duno M, Hayward NK, Gerdes AM.
Molecular characterization of melanoma cases in Denmark suspected of genetic predisposition. PLOS ONE 2015;10:e0122662.

20 Testa JR, Cheung M, Pei J, Below JE, Tan Y, Sementino E, Cox NJ, Dogan AU, Pass HI, Trusa S, Hesdorffer M, Nasu M, Powers A, Rivera Z, Comertpay S, Tanji M, Gaudino G, Yang H, Carbone M. Germline BAP1 mutations predispose to malignant mesothelioma. Nat Genet 2011;43:1022-5.

21 Wiesner T, Obenauf AC, Murali R, Fried I, Griewank KG, Ulz P, Windpassinger C, Wackernagel W, Loy S, Wolf I, Viale A, Lash AE, Pirun M, Socci ND, Rutten A, Palmedo G, Abramson D, Offit K, Ott A, Becker JC, Cerroni L, Kutzner H, Bastian BC, Speicher MR. Germline mutations in BAP1 predispose to melanocytic tumors. Nat Genet 2011;43:1018-21.

22 Abdel-Rahman MH, Pilarski R, Cebulla CM, Massengill JB, Christopher BN, Boru G, Hovland P, Davidorf FH. Germline BAP1 mutation predisposes to uveal melanoma, lung adenocarcinoma, meningioma, and other cancers. J Med Genet 2011:48:856-9.

23 Njauw CN, Kim I, Piris A, Gabree M, Taylor M, Lane AM, DeAngelis MM, Gragoudas E, Duncan LM, Tsao H. Germline BAP1 inactivation is preferentially associated with metastatic ocular melanoma and cutaneous-ocular melanoma families. PLOS ONE 2012;7:e35295.

24 Wadt K, Choi J, Chung JY, Kiilgaard J, Heegaard S, Drzewiecki KT, Trent JM, Hewitt SM, Hayward NK, Gerdes AM, Brown KM. A cryptic BAP1 splice mutation in a family with uveal and cutaneous melanoma, and paraganglioma. Pigment Cell Melanoma Res 2012;25:815-18.

25 Aoude LG, Wadt K, Bojesen A, Cruger D, Borg A, Trent JM, Brown KM, Gerdes AM, Jonsson G, Hayward NK. A BAP1 mutation in a Danish family predisposes to uveal melanoma and other cancers. PLoS One 2013;8:e72144.

26 Popova T, Hebert L, Jacquemin V, Gad S, Caux-Moncoutier V, Dubois-d'Enghien C, Richaudeau B, Renaudin X, Sellers J, Nicolas A, Sastre-Garau X, Desjardins L, Gyapay G, Raynal V, Sinilnikova OM, Andrieu N, Manie E, de Pauw A, Gesta P, Bonadona V, Maugard CM, Penet C, Avril MF, Barillot E, Cabaret O, Delattre O, Richard S, Caron O, Benfodda M, Hu HH, Soufir N, Bressac-de Paillerets B, Stoppa-Lyonnet D, Stern MH. Germline BAP1 mutations predispose to renal cell carcinomas. Am J Hum Genet 2013;92:974-80.

27 de la Fouchardiere A, Cabaret O, Savin L, Combemale P, Schvartz H, Penet C, Bonadona V, Soufir N, Bressac-de Paillerets B. Germline BAP1 mutations predispose also to multiple basal cell carcinomas. Clin Genet 2015;88:273-7.

28 Wadt KA, Aoude LG, Johansson P, Solinas A, Pritchard A, Crainic O, Andersen MT, Kiilgaard JF, Heegaard S, Sunde L, Federspiel B, Madore J, Thompson JF, McCarthy SW, Goodwin A, Tsao H, Jonsson G, Busam K, Gupta R, Trent JM, Gerdes AM, Brown KM, Scolyer RA, Hayward NK. A recurrent germline BAP1 mutation and extension of the BAP1 tumor predisposition spectrum to include basal cell carcinoma. Clin Genet 2015;88:267-72.

29 Wiesner T, Fried I, Ulz P, Stacher E, Popper H, Murali R, Kutzner H, Lax S, Smolle-Juttner F, Geigl JB, Speicher MR. Toward an improved definition of the tumor spectrum associated with BAP1 germline mutations. J Clin Oncol 2012;30: e337-40.

30 Carbone M, Yang H, Pass HI, Krausz T, Testa JR, Gaudino G. BAP1 and cancer. Nat Rev Cancer 2013:13:153-9.

31 Wiesner T, Murali R, Fried I, Cerroni L, Busam K, Kutzner H, Bastian BC. A distinct subset of atypical Spitz tumors is characterized by BRAF mutation and loss of BAP1 expression. Am J Surg Pathol 2012;36:818-30.

32 Hoiom V, Edsgard D, Helgadottir H, Eriksson H, All-Ericsson C, Tuominen R, Ivanova I, Lundeberg J, Emanuelsson 0, Hansson J. Hereditary uveal melanoma: a report of a germline mutation in BAP1. Genes Chromosomes Cancer 2013:52:378-84.

33 Cheung M, Talarchek J, Schindeler K, Saraiva E, Penney LS, Ludman M, Testa JR Further evidence for germline BAP1 mutations predisposing to melanoma and malignant mesothelioma. Cancer Genet 2013;206:206-10.

34 Maerker DA, Zeschnigk M, Nelles J, Lohmann DR, Worm K, Bosserhoff AK, Krupar $R$, Jagle $H$. BAP1 germline mutation in two first grade family members with uveal melanoma. Br J Ophthalmol 2014;98:224-7.

35 Pilarski R, Cebulla CM, Massengill JB, Rai K, Rich T, Strong L, McGillivray B, Asrat MJ, Davidorf FH, Abdel-Rahman MH. Expanding the clinical phenotype of hereditary BAP1 cancer predisposition syndrome, reporting three new cases. Genes Chromosomes Cancer 2014;53:177-82.

36 Murali R, Wilmott JS, Jakrot V, Al-Ahmadie HA, Wiesner T, McCarthy SW, Thompson JF, Scolyer RA. BAP1 expression in cutaneous melanoma: a pilot study. Pathology 2013;45:606-9.

37 Flynn RL, Zou L. Oligonucleotide/oligosaccharide-binding fold proteins: a growing family of genome guardians. Crit Rev Biochem Mol Biol 2010;45:266-75.

38 Robles-Espinoza CD, Harland M, Ramsay AJ, Aoude LG, Quesada V, Ding Z, Pooley KA, Pritchard AL, Tiffen JC, Petljak M, Palmer JM, Symmons J, Johansson P, Stark MS, Gartside MG, Snowden H, Montgomery GW, Martin NG, Liu JZ, Choi J, Makowski M, Brown KM, Dunning AM, Keane TM, López-Otín C, Gruis NA, Hayward NK, Bishop DT, Newton-Bishop JA, Adams DJ. POT1 loss-of-function variants predispose to familial melanoma. Nat Genet 2014;46:478-81.

39 Shi J, Yang XR, Ballew B, Rotunno M, Calista D, Fargnoli MC, Ghiorzo P, Bressac-de Paillerets B, Nagore E, Avril MF, Caporaso NE, McMaster ML, Cullen 
M, Wang Z, Zhang X, Bruno W, Pastorino L, Queirolo P, Banuls-Roca J, Garcia-Casado Z, Vaysse A, Mohamdi H, Riazalhosseini Y, Foglio M, Jouenne F, Hua X, Hyland PL, Yin J, Vallabhaneni H, Chai W, Minghetti P, Pellegrini C, Ravichandran S, Eggermont A, Lathrop M, Peris K, Scarra GB, Landi G, Savage SA, Sampson JN, He J, Yeager M, Goldin LR, Demenais F, Chanock SJ, Tucker MA, Goldstein AM, Liu Y, Landi MT. Rare missense variants in POT1 predispose to familial cutaneous malignant melanoma. Nat Genet 2014;46:482-6.

40 Burke LS, Hyland PL, Pfeiffer RM, Prescott J, Wheeler W, Mirabello L, Savage SA, Burdette L, Yeager M, Chanock S, De Vivo I, Tucker MA, Goldstein AM, Yang XR. Telomere length and the risk of cutaneous malignant melanoma in melanoma-prone families with and without CDKN2A mutations. PLOS ONE 2013:8:e71121.

41 Aoude LG, Pritchard AL, Robles-Espinoza CD, Wadt K, Harland M, Choi J, Gartside M, Quesada V, Johansson P, Palmer JM, Ramsay AJ, Zhang X, Jones K, Symmons J, Holland EA, Schmid H, Bonazzi V, Woods S, Dutton-Regester K, Stark MS, Snowden H, van Doorn R, Montgomery GW, Martin NG, Keane TM, López-Otín C, Gerdes AM, Olsson H, Ingvar C, Borg A, Gruis NA, Trent JM, Jönsson G, Bishop DT, Mann GJ, Newton-Bishop JA, Brown KM, Adams DJ, Hayward NK. Nonsense Mutations in the Shelterin Complex Genes ACD and TERF2IP in Familial Melanoma. J Nat/ Cancer Inst 2014;107:pii: dju408.

42 Vinagre J, Almeida A, Populo H, Batista R, Lyra J, Pinto V, Coelho R, Celestino R, Prazeres H, Lima L, Melo M, da Rocha AG, Preto A, Castro P, Castro L, Pardal F, Lopes JM, Santos LL, Reis RM, Cameselle-Teijeiro J, Sobrinho-Simoes M, Lima J, Maximo V, Soares P. Frequency of TERT promoter mutations in human cancers. Nat Commun 2013:4:2185.

43 Horn S, Figl A, Rachakonda PS, Fischer C, Sucker A, Gast A, Kadel S, Moll I, Nagore E, Hemminki K, Schadendorf D, Kumar R. TERT promoter mutations in familial and sporadic melanoma. Science 2013;339:959-61.

44 Lu Y, Ek WE, Whiteman D, Vaughan TL, Spurdle AB, Easton DF, Pharoah PD, Thompson DJ, Dunning AM, Hayward NK, Chenevix-Trench G, Macgregor S. Most common 'sporadic' cancers have a significant germline genetic component. Hum Mol Genet 2014:23:6112-18.

45 Beaumont KA, Shekar SN, Newton RA, James MR, Stow JL, Duffy DL, Sturm RA. Receptor function, dominant negative activity and phenotype correlations for MC1R variant alleles. Hum Mol Genet 2007;16:2249-60.

46 Beaumont KA, Newton RA, Smit DJ, Leonard JH, Stow JL, Sturm RA. Altered cell surface expression of human MC1R variant receptor alleles associated with red hair and skin cancer risk. Hum Mol Genet 2005;14:2145-54.

47 Newton RA, Roberts DW, Leonard JH, Sturm RA. Human melanocytes expressing MC1R variant alleles show impaired activation of multiple signaling pathways. Peptides 2007;28:2387-96.

48 Hu HH, Benfodda M, Dumaz N, Gazal S, Descamps V, Bourillon A, Basset-Seguin N, Riffault A, Ezzedine K, Bagot M, Bensussan A, Saiag P, Grandchamp B, Soufir $\mathrm{N}$. A large french case-control study emphasizes the role of rare Mc1R variants in melanoma risk. Biomed Res Int 2014;2014:925716.

49 Pasquali E, Garcia-Borron JC, Fargnoli MC, Gandini S, Maisonneuve P, Bagnardi V, Specchia C, Liu F, Kayser M, Nijsten T, Nagore E, Kumar R, Hansson J, Kanetsky PA, Ghiorzo P, Debniak T, Branicki W, Gruis NA, Han J, Dwyer T, Blizzard L, Landi MT, Palmieri G, Ribas G, Stratigos A, Council ML, Autier P, Little J, Newton-Bishop J, Sera F, Raimondi S. MC1R variants increased the risk of sporadic cutaneous melanoma in darker-pigmented Caucasians: a pooled-analysis from the M-SKIP project. Int I Cancer 2015;136:618-31.

50 Kanetsky PA, Panossian S, Elder DE, Guerry D, Ming ME, Schuchter L, Rebbeck TR. Does MC1R genotype convey information about melanoma risk beyond risk phenotypes? Cancer 2010;116:2416-28.

51 Jarrett SG, Wolf Horrell EM, Christian PA, Vanover JC, Boulanger MC, Zou Y, D'Orazio JA. PKA-mediated phosphorylation of ATR promotes recruitment of XPA to UV-induced DNA damage. Mol Cell 2014;54:999-1011.

52 Kadekaro AL, Chen J, Yang J, Chen S, Jameson J, Swope VB, Cheng T, Kadakia M, Abdel-Malek Z. Alpha-melanocyte-stimulating hormone suppresses oxidative stress through a p53-mediated signaling pathway in human melanocytes. $\mathrm{Mol}$ Cancer Res 2012;10:778-86.

53 Kadekaro AL, Leachman S, Kavanagh RJ, Swope V, Cassidy P, Supp D, Sartor M, Schwemberger S, Babcock G, Wakamatsu K, Ito S, Koshoffer A, Boissy RE, Manga P, Sturm RA, Abdel-Malek ZA. Melanocortin 1 receptor genotype: an important determinant of the damage response of melanocytes to ultraviolet radiation. Faseb j 2010;24:3850-60.

54 Bertolotto $C$, Lesueur F, Giuliano S, Strub T, de Lichy M, Bille K, Dessen P, d'Hayer $B$, Mohamdi $H$, Remenieras A, Maubec E, de la Fouchardiere A, Molinie V, Vabres $P$, Dalle S, Poulalhon N, Martin-Denavit T, Thomas L, Andry-Benzaquen P, Dupin N, Boitier F, Rossi A, Perrot IL, Labeille B, Robert C, Escudier B, Caron O, Brugieres L, Saule S, Gardie B, Gad S, Richard S, Couturier J, Teh BT, Ghiorzo P, Pastorino L, Puig S, Badenas C, Olsson H, Ingvar C, Rouleau E, Lidereau R, Bahadoran $\mathrm{P}$, Vielh P, Corda E, Blanche H, Zelenika D, Galan P, Aubin F, Bachollet $B$, Becuwe C, Berthet P, Bignon YJ, Bonadona V, Bonafe JL, Bonnet-Dupeyron MN, Cambazard F, Chevrant-Breton J, Coupier I, Dalac S, Demange L, d'Incan M, Dugast C, Faivre L, Vincent-Fetita L, Gauthier-Villars M, Gilbert B, Grange F, Grob JJ, Humbert P, Janin N, Joly P, Kerob D, Lasset C, Leroux D, Levang J, Limacher
JM, Livideanu C, Longy M, Lortholary A, Stoppa-Lyonnet D, Mansard S, Mansuy L, Marrou K, Mateus C, Maugard C, Meyer N, Nogues C, Souteyrand P, Venat-Bouvet L, Zattara H, Chaudru V, Lenoir GM, Lathrop M, Davidson I, Avril MF, Demenais F, Ballotti R, Bressac-de Paillerets B. A SUMOylation-defective MITF germline mutation predisposes to melanoma and renal carcinoma. Nature 2011:480:94-8.

55 Yokoyama S, Woods SL, Boyle GM, Aoude LG, MacGregor S, Zismann V, Gartside M, Cust AE, Haq R, Harland M, Taylor JC, Duffy DL, Holohan K, Dutton-Regester K, Palmer JM, Bonazzi V, Stark MS, Symmons J, Law MH, Schmidt C, Lanagan C, $\mathrm{O}^{\prime}$ Connor L, Holland EA, Schmid $\mathrm{H}$, Maskiell JA, Jetann J, Ferguson M, Jenkins MA, Kefford RF, Giles GG, Armstrong BK, Aitken JF, Hopper JL, Whiteman DC, Pharoah PD, Easton DF, Dunning AM, Newton-Bishop JA, Montgomery GW, Martin NG, Mann GJ, Bishop DT, Tsao H, Trent JM, Fisher DE, Hayward NK, Brown KM. A novel recurrent mutation in MITF predisposes to familial and sporadic melanoma. Nature 2011;480:99-103.

56 Murakami H, Arnheiter H. Sumoylation modulates transcriptional activity of MITF in a promoter-specific manner. Pigment Cell Res 2005;18:265-77.

57 Ghiorzo P, Pastorino L, Queirolo P, Bruno W, Tibiletti MG, Nasti S, Andreotti V, Paillerets BB, Bianchi Scarra G. Prevalence of the E318K MITF germline mutation in Italian melanoma patients: associations with histological subtypes and family cancer history. Pigment Cell Melanoma Res 2013;26:259-62.

58 Sturm RA, Fox C, McClenahan P, Jagirdar K, Ibarrola-Villava M, Banan P, Abbott NC, Ribas G, Gabrielli B, Duffy DL, Soyer HP. Phenotypic characterization of nevus and tumor patterns in MITF E318K mutation carrier melanoma patients. J Invest Dermatol 2014;134:141-9.

59 Ibarrola-Villava M, Fernandez LP, Alonso S, Boyano MD, Pena-Chilet M, Pita G, Aviles JA, Mayor M, Gomez-Fernandez C, Casado B, Martin-Gonzalez M, Izagirre $\mathrm{N}$, De la Rua C, Asumendi A, Perez-Yarza G, Arroyo-Berdugo Y, Boldo E, Lozoya R, Torrijos-Aguilar A, Pitarch A, Pitarch G, Sanchez-Motilla JM, Valcuende-Cavero F, Tomas-Cabedo G, Perez-Pastor G, Diaz-Perez JL, Gardeazabal J, Martinez de Lizarduy I, Sanchez-Diez A, Valdes C, Pizarro A, Casado M, Carretero G, Botella-Estrada R, Nagore E, Lazaro P, Lluch A, Benitez J, Martinez-Cadenas C, Ribas $G$. A customized pigmentation SNP array identifies a novel SNP associated with melanoma predisposition in the SLC45A2 gene. PLOS ONE 2011;6:e19271.

60 Ibarrola-Villava M, Hu HH, Guedj M, Fernandez LP, Descamps V, Basset-Seguin N, Bagot M, Benssussan A, Saiag P, Fargnoli MC, Peris K, Aviles JA, Lluch A, Ribas G, Soufir N. MC1R, SLC45A2 and TYR genetic variants involved in melanoma susceptibility in southern European populations: results from a meta-analysis. Eur $\mathrm{J}$ Cancer 2012;48:2183-91.

61 Duffy DL, Zhao ZZ, Sturm RA, Hayward NK, Martin NG, Montgomery GW. Multiple pigmentation gene polymorphisms account for a substantial proportion of risk of cutaneous malignant melanoma. J Invest Dermatol 2010;130:520-8.

62 Kocarnik JM, Park SL, Han J, Dumitrescu L, Cheng I, Wilkens LR, Schumacher FR, Kolonel L, Carlson CS, Crawford DC, Goodloe RJ, Dilks H, Baker P, Richardson D, Ambite JL, Song F, Quresh AA, Zhang M, Duggan D, Hutter C, Hindorff LA, Bush WS, Kooperberg C, Le Marchand L, Peters U. Replication of associations between GWAS SNPs and Melanoma risk in the Population Architecture Using Genomics and Epidemiology (PAGE) study. J Invest Dermatol 2014:134:2049-52.

63 Guedj M, Bourillon A, Combadieres C, Rodero M, Dieude P, Descamps V, Dupin $\mathrm{N}$, Wolkenstein $\mathrm{P}$, Aegerter $\mathrm{P}$, Lebbe $C$, Basset-Seguin N, Prum B, Saiag $\mathrm{P}$, Grandchamp B, Soufir N. Variants of the MATP/SLC45A2 gene are protective for melanoma in the French population. Hum Mutat 2008;29:1154-60.

64 Raimondi S, Sera F, Gandini S, lodice S, Caini S, Maisonneuve P, Fargnoli MC. MC1R variants, melanoma and red hair color phenotype: a meta-analysis. Int J Cancer 2008;122:2753-60.

65 Barrett JH, lles MM, Harland M, Taylor JC, Aitken JF, Andresen PA, Akslen LA, Armstrong BK, Avril MF, Azizi E, Bakker B, Bergman W, Bianchi-Scarra G, Bressac-de Paillerets B, Calista D, Cannon-Albright LA, Corda E, Cust AE, Debniak T, Duffy D, Dunning AM, Easton DF, Friedman E, Galan P, Ghiorzo P, Giles GG, Hansson J, Hocevar M, Hoiom V, Hopper JL, Ingvar C, Janssen B, Jenkins MA, Jonsson G, Kefford RF, Landi G, Landi MT, Lang J, Lubinski J, Mackie R, Malvehy J, Martin NG, Molven A, Montgomery GW, van Nieuwpoort FA, Novakovic S, Olsson H, Pastorino L, Puig S, Puig-Butille JA, Randerson-Moor J, Snowden H, Tuominen R, Van Belle P, van der Stoep N, Whiteman DC, Zelenika D, Han J, Fang S, Lee JE, Wei Q, Lathrop GM, Gillanders EM, Brown KM, Goldstein AM, Kanetsky PA, Mann GJ, Macgregor S, Elder DE, Amos Cl, Hayward NK, Gruis NA, Demenais F, Bishop JA, Bishop DT. Genome-wide association study identifies three new melanoma susceptibility loci. Nat Genet 2011;43:1108-13.

66 Gudbjartsson DF, Sulem P, Stacey SN, Goldstein AM, Rafnar T, Sigurgeirsson B, Benediktsdottir KR, Thorisdottir $K$, Ragnarsson $R$, Sveinsdottir SG, Magnusson $V$, Lindblom A, Kostulas K, Botella-Estrada R, Soriano V, Juberias P, Grasa M, Saez B, Andres R, Scherer D, Rudnai P, Gurzau E, Koppova K, Kiemeney LA, Jakobsdottir M, Steinberg S, Helgason A, Gretarsdottir S, Tucker MA, Mayordomo Jl, Nagore E, Kumar R, Hansson J, Olafsson JH, Gulcher J, Kong A, Thorsteinsdottir U, Stefansson K. ASIP and TYR pigmentation variants associate with cutaneous melanoma and basal cell carcinoma. Nat Genet 2008;40:886-91.

67 Amos $\mathrm{Cl}$, Wang LE, Lee JE, Gershenwald JE, Chen WV, Fang S, Kosoy R, Zhang M, Qureshi AA, Vattathil S, Schacherer CW, Gardner JM, Wang Y, Bishop DT, 
Barrett JH, MacGregor S, Hayward NK, Martin NG, Duffy DL, Mann GJ, Cust A, Hopper J, Brown KM, Grimm EA, Xu Y, Han Y, Jing K, McHugh C, Laurie CC, Doheny KF, Pugh EW, Seldin MF, Han J, Wei Q. Genome-wide association study identifies novel loci predisposing to cutaneous melanoma. Hum Mol Genet 2011;20:5012-23.

68 Sturm RA, Duffy DL, Zhao ZZ, Leite FP, Stark MS, Hayward NK, Martin NG, Montgomery GW. A single SNP in an evolutionary conserved region within intron 86 of the HERC2 gene determines human blue-brown eye color. Am J Hum Genet 2008;82:424-31.

$69 \mathrm{Nan} \mathrm{H}$, Kraft P, Hunter DJ, Han J. Genetic variants in pigmentation genes, pigmentary phenotypes, and risk of skin cancer in Caucasians. Int I Cancer 2009;125:909-17.

70 Chatzinasiou F, Lill CM, Kypreou K, Stefanaki I, Nicolaou V, Spyrou G, Evangelou E, Roehr JT, Kodela E, Katsambas A, Tsao H, loannidis JPA, Bertram L, Stratigos AJ. Comprehensive Field Synopsis and Systematic Meta-analyses of Genetic Association Studies in Cutaneous Melanoma. I Natl Cancer Inst 2011:103:1227-35.

71 Jannot A-S, Meziani R, Bertrand G, Gerard B, Descamps V, Archimbaud A, Picard C, Ollivaud L, Basset-Seguin N, Kerob D, Lanternier G, Lebbe C, Saiag P, Crickx B, Clerget-Darpoux F, Grandchamp B, Soufir N, Melan C. Allele variations in the OCA2 gene (pink-eyed-dilution locus) are associated with genetic susceptibility to melanoma. Eur J Hum Genet 2005;13:913-20.

72 Fernandez LP, Milne RL, Pita G, Avilés JA, Lázaro P, Benítez J, Ribas G. SLC45A2: a novel malignant melanoma-associated gene. Hum Mutat 2008;29:1161-7.

73 Law MH, Bishop DT, Lee JE, Brossard M, Martin NG, Moses EK, Song F, Barrett JH, Kumar R, Easton D, Pharoah PD, Swerdlow AJ, Kypreou K, Taylor JC, Harland M, Randerson-Moor J, Akslen LA, Andresen PA, Avril MF, Azizi E, Scarra GB, Brown KM, Debniak B, Duffy D, Elder DE, Fang S, Friedman E, Galan P, Ghiorzo P, Gillanders EM, Goldstein AM, Gruis NA, Hansson J, Helsing P, Hocevar M, Hoiom V, Ingvar C, Kanetsky P, Chen WV, Consortium G, Investigators E-H, Group TSS, Investigators Q-MaQ, Investigators A, Group AMS, Landi MT, Lang J, Lathrop M, Lubinski J, Mackie R, Mann GJ, Molven A, Montgomery GW, Novakovic S, Olsson H, Puig S, Puig-Butille JA, Qureshi AA, Radford-Smith GL, van der Stoep N, van Doorn $R$, Whiteman $D$, Craig JE, Schadendorf $D$, Simms $L A$, Burdon KP, Nyholt DR, Pooley KA, Orr N, Stratigos A, Cust A, Ward SV, Hayward NK, Han J, Schulze HJ, Dunning AM, Newton Bishop J, Demenais F, Amos Cl, MacGregor S, lles MM. Genome-wide meta-analysis identifies five new susceptibility loci for cutaneous malignant melanoma. Nat Genet Published Online First: 3 Aug 2015 doi:10.1038/ng.3373

74 Kanetsky PA, Swoyer J, Panossian S, Holmes R, Guerry D, Rebbeck TR. A polymorphism in the agouti signaling protein gene is associated with human pigmentation. Am J Hum Genet 2002;70:770-5.

75 Meziani R, Descamps V, Gérard B, Matichard E, Bertrand G, Archimbaud A, Ollivaud L, Saiag P, Lebbé C, Basset-Seguin N, Alberti C, Crickx B, Grandchamp B, Soufir N. Association study of the g.8818A $>G$ polymorphism of the human agouti gene with melanoma risk and pigmentary characteristics in a French population. J Dermatol Sci 2005;40:133-6.

76 Falchi M, Bataille V, Hayward NK, Duffy DL, Bishop JAN, Pastinen T, Cervino A, Zhao ZZ, Deloukas P, Soranzo N, Elder DE, Barrett JH, Martin NG, Bishop DT, Montgomery GW, Spector TD. Genome-wide association study identifies variants at 9p21 and 22q13 associated with development of cutaneous nevi. Nat Genet 2009;41:915-19.

77 Law MH, Montgomery GW, Brown KM, Martin NG, Mann GJ, Hayward NK, MacGregor S, Q-MEGA and AMFS Investigators. Meta-analysis combining new and existing data sets confirms that the TERT-CLPTM1L locus influences melanoma risk. J Invest Dermatol 2012;132:485-7.

78 lles MM, Law MH, Stacey SN, Han J, Fang S, Pfeiffer R, Harland M, MacGregor S, Taylor JC, Aben KK, Akslen LA, Avril M-F, Azizi E, Bakker B, Benediktsdottir KR, Bergman W, Scarrà GB, Brown KM, Calista D, Chaudru V, Fargnoli MC, Cust AE, Demenais F, de Waal AC, Dębniak T, Elder DE, Friedman E, Galan P, Ghiorzo P, Gillanders EM, Goldstein AM, Gruis NA, Hansson J, Helsing P, Hočevar M, Höiom V, Hopper JL, Ingvar C, Janssen M, Jenkins MA, Kanetsky PA, Kiemeney LA, Lang J, Lathrop GM, Leachman S, Lee JE, Lubiński J, Mackie RM, Mann GJ, Mayordomo Jl, Molven A, Mulder S, Nagore E, Novaković S, Okamoto I, Olafsson JH, Olsson H, Pehamberger H, Peris K, Grasa MP, Planelles D, Puig S, Puig-Butille JA, Randerson-Moor J, Requena C, Rivoltini L, Rodolfo M, Santinami M, Sigurgeirsson B, Snowden H, Song F, Sulem P, Thorisdottir K, Tuominen R, Van Belle P, van der Stoep $\mathrm{N}$, van Rossum MM, Wei Q, Wendt J, Zelenika D, Zhang M, Landi MT, Thorleifsson $G$, Bishop DT, Amos Cl, Hayward NK, Stefansson K, Bishop JAN, Barrett JH, GenoMEL Consortium, Q-MEGA and AMFS Investigators. A variant in FTO shows association with melanoma risk not due to BMI. Nat Genet 2013;45:428-32.

79 MacGregor S, Montgomery GW, Liu JZ, Zhao ZZ, Henders AK, Stark M, Schmid H, Holland EA, Duffy DL, Zhang M, Painter JN, Nyholt DR, Maskiell JA, Jetann J, Ferguson $M$, Cust $A E$, Jenkins MA, Whiteman DC, Olsson $H$, Puig $S$, Bianchi-Scarrà G, Hansson J, Demenais F, Landi MT, Debniak T, Mackie R, Azizi E, Bressac-de Paillerets B, Goldstein AM, Kanetsky PA, Gruis NA, Elder DE, Newton-Bishop JA, Bishop DT, lles MM, Helsing P, Amos Cl, Wei Q, Wang L-E, Lee JE, Qureshi AA, Kefford RF, Giles GG, Armstrong BK, Aitken JF, Han J, Hopper
JL, Trent JM, Brown KM, Martin NG, Mann GJ, Hayward NK. Genome-wide association study identifies a new melanoma susceptibility locus at 1q21.3. Nat Genet 2011:43:1114-18.

80 Zhang M, Qureshi AA, Guo Q, Han J. Genetic variation in DNA repair pathway genes and melanoma risk. DNA Repair (Amst) 2011;10:111-16.

81 Xiao F, Ma J, Cai G, Fang S, Lee JE, Wei Q, Amos Cl. Natural and orthogonal model for estimating gene-gene interactions applied to cutaneous melanoma. Hum Genet 2014:133:559-74.

82 Berwick M, MacArthur J, Orlow I, Kanetsky P, Begg CB, Luo L, Reiner A, Sharma A, Armstrong BK, Kricker A, Cust AE, Marrett LD, Gruber SB, Anton-Culver H, Zanetti R, Rosso S, Gallagher RP, Dwyer T, Venn A, Busam K, From L, White K, Thomas NE. MITF E318K's effect on melanoma risk independent of, but modified by, other risk factors. Pigment Cell Melanoma Res 2014;27:485-8.

83 Cao J, Wan L, Hacker E, Dai X, Lenna S, Jimenez-Cervantes C, Wang Y, Leslie NR, Xu GX, Widlund HR, Ryu B, Alani RM, Dutton-Regester K, Goding CR, Hayward NK, Wei W, Cui R. MC1R is a potent regulator of PTEN after UV exposure in melanocytes. Mol Cell 2013;51:409-22.

84 Mukherjee B, Delancey JO, Raskin L, Everett J, Jeter J, Begg CB, Orlow I, Berwick M, Armstrong BK, Kricker A, Marrett LD, Millikan RC, Culver HA, Rosso S, Zanetti R, Kanetsky PA, From L, Gruber SB. Risk of non-melanoma cancers in firstdegree relatives of CDKN2A mutation carriers. J Natl Cancer Inst 2012; 104:953-6.

85 Potrony M, Puig-Butille JA, Aguilera P, Badenas C, Carrera C, Malvehy J, Puig S. Increased prevalence of lung, breast, and pancreatic cancers in addition to melanoma risk in families bearing the cyclin-dependent kinase inhibitor $2 \mathrm{~A}$ mutation: implications for genetic counseling. J Am Acad Dermatol 2014;71:888-95.

86 Li WQ, Pfeiffer RM, Hyland PL, Shi J, Gu F, Wang Z, Bhattacharjee S, Luo J, Xiong X, Yeager M, Deng X, Hu N, Taylor PR, Albanes D, Caporaso NE, Gapstur SM, Amundadottir L, Chanock SJ, Chatterjee N, Landi MT, Tucker MA, Goldstein AM, Yang XR. Genetic polymorphisms in the 9p21 region associated with risk of multiple cancers. Carcinogenesis 2014;35:2698-705.

87 Ramsay AJ, Quesada V, Foronda M, Conde L, Martinez-Trillos A, Villamor N, Rodriguez D, Kwarciak A, Garabaya C, Gallardo M, Lopez-Guerra M, Lopez-Guillermo A, Puente XS, Blasco MA, Campo E, Lopez-Otin C. POT1 mutations cause telomere dysfunction in chronic lymphocytic leukemia. Nat Genet 2013:45:526-30.

88 Speedy HE, Di Bernardo MC, Sava GP, Dyer MJ, Holroyd A, Wang Y, Sunter NJ, Mansouri L, Juliusson G, Smedby KE, Roos G, Jayne S, Majid A, Dearden C, Hall AG, Mainou-Fowler T, Jackson GH, Summerfield G, Harris RJ, Pettitt AR, Allsup DJ Bailey JR, Pratt G, Pepper C, Fegan C, Rosenquist R, Catovsky D, Allan JM, Houlston RS. A genome-wide association study identifies multiple susceptibility loci for chronic lymphocytic leukemia. Nat Genet 2014;46:56-60.

89 Bainbridge MN, Armstrong GN, Gramatges MM, Bertuch AA, Jhangiani SN, Doddapaneni H, Lewis L, Tombrello J, Tsavachidis S, Liu Y, Jalali A, Plon SE, Lau CC, Parsons DW, Claus EB, Barnholtz-Sloan J, Il'yasova D, Schildkraut J, Ali-Osman F, Sadetzki S, Johansen C, Houlston RS, Jenkins RB, Lachance D, Olson SH, Bernstein JL, Merrell RT, Wrensch MR, Walsh KM, Davis FG, Lai R, Shete $S$, Aldape K, Amos Cl, Thompson PA, Muzny DM, Gibbs RA, Melin BS, Bondy ML, Gliogene Consortium. Germline mutations in shelterin complex genes are associated with familial glioma. J Natl Cancer Inst 2014;107:384.

90 Scheurer ME, Etzel CJ, Liu M, El-Zein R, Airewele GE, Malmer B, Aldape KD, Weinberg JS, Yung WK, Bondy ML. Aggregation of cancer in first-degree relatives pf patients with glioma. Cancer Epidemiol Biomarkers Prev 2007:16:2491-5.

91 Shete S, Hosking FJ, Robertson LB, Dobbins SE, Sanson M, Malmer B, Simon M, Marie Y, Boisselier B, Delattre JY, Hoang-Xuan K, El Hallani S, Idbaih A, Zelenika $D$, Andersson U, Henriksson R, Bergenheim AT, Feychting M, Lönn S, Ahlbom A, Schramm J, Linnebank M, Hemminki K, Kumar R, Hepworth SJ, Price A, Armstrong G, Liu Y, Gu X, Yu R, Lau C, Schoemaker M, Muir K, Swerdlow A, Lathrop M, Bondy $M$, Houlston RS. Genome-wide association study identifies five susceptibility loci for glioma. Nat Genet 2009;41:899-904.

92 Wrensch $M$, Jenkins RB, Chang JS, Yeh RF, Xiao Y, Decker PA, Ballman KV, Berger M, Buckner JC, Chang S, Giannini C, Halder C, Kollmeyer TM, Kosel ML, LaChance DH, McCoy L, O'Neill BP, Patoka J, Pico AR, Prados M, Quesenberry C, Rice T, Rynearson AL, Smirnov I, Tihan T, Wiemels J, Yang P, Wiencke JK. Variants in the CDKN2B and RTEL1 genes are associated with high-grade glioma susceptibility. Nat Genet 2009:41:905-8.

93 Laliotis A, Vrekoussis T, Kafousi M, Sanidas E, Askoxilakis J, Melissas J, Mavroudis D, Castanas E, Stathopoulos EN. Immunohistochemical study of pElk-1 expression in human breast cancer: association with breast cancer biologic profile and clinicopathologic features. Breast 2013:22:89-95.

94 Pallai R, Bhaskar A, Sodi V, Rice LM. Ets1 and Elk1 transcription factors regulate cancerous inhibitor of protein phosphatase $2 \mathrm{~A}$ expression in cervical and endometrial carcinoma cells. Transcription 2012:3:323-35.

95 Shore P, Sharrocks AD. The ETS-domain transcription factors Elk-1 and SAP-1 exhibit differential DNA binding specifitoies. Nucleic Acids Res 1995;23:4698-706. 
96 Abern M, Tsivian M, Coogan C, Kaufman H, Polascik T. Characteristics of patients diagnosed with both melanoma and renal cell cancer. Cancer Causes Control 2013;24:1925-33.

97 Farley MN, Schmidt LS, Mester JL, Pena-Llopis S, Pavia-Jimenez A, Christie A, Vocke CD, Ricketts CJ, Peterson J, Middelton L, Kinch L, Grishin N, Merino MJ, Metwalli AR, Xing C, Xie XJ, Dahia PL, Eng C, Linehan WM, Brugarolas J. A novel germline mutation in BAP1 predisposes to familial clear-cell renal cell carcinoma. Mol Cancer Res 2013:11:1061-71.

98 Olivier M, Goldgar DE, Sodha N, Ohgaki H, Kleihues P, Hainaut P, Eeles RA. Li-Fraumeni and related syndromes: correlation between tumor type, family structure, and TP53 genotype. Cancer Res 2003;63:6643-50.

99 Ruijs MW, Verhoef $S$, Rookus MA, Pruntel $R$, van der Hout $A H$, Hogervorst FB, Kluijt I, Sijmons RH, Aalfs CM, Wagner A, Ausems MG, Hoogerbrugge N, van Asperen CJ, Gomez Garcia EB, Meijers-Heijboer H, Ten Kate LP, Menko FH, van 't Veer LJ. TP53 germline mutation testing in 180 families suspected of Li-Fraumeni syndrome: mutation detection rate and relative frequency of cancers in different familial phenotypes. J Med Genet 2010;47:421-8.

100 Curiel-Lewandrowski C, Speetzen LS, Cranmer L, Warneke JA, Loescher LJ. Multiple primary cutaneous melanomas in Li-Fraumeni syndrome. Arch Dermatol 2011;147:248-50

101 Bradford PT, Goldstein AM, Tamura D, Khan SG, Ueda T, Boyle J, Oh KS, Imoto K, Inui H, Moriwaki S, Emmert S, Pike KM, Raziuddin A, Plona TM, DiGiovanna JJ, Tucker MA, Kraemer KH. Cancer and neurologic degeneration in xeroderma pigmentosum: long term follow-up characterises the role of DNA repair. J Med Genet 2011;48:168-76.

102 Lauper JM, Krause A, Vaughan TL, Monnat RJ Jr. Spectrum and risk of neoplasia in Werner syndrome: a systematic review. PLOS ONE 2013;8:e59709.

103 Moran A, O'Hara C, Khan S, Shack L, Woodward E, Maher ER, Lalloo F, Evans DG. Risk of cancer other than breast or ovarian in individuals with BRCA1 and BRCA2 mutations. Fam Cancer 2012;11:235-42.

104 Breast Cancer Linkage Consortium. Cancer risks in BRCA2 mutation carriers. J Nat/ Cancer Inst 1999;91:1310-16.

105 Robson ME, Storm CD, Weitzel J, Wollins DS, Offit K, American Society of Clinical Oncology. American Society of Clinical Oncology Policy Statement Update: genetic and genomic testing for cancer susceptibility. J Clin Oncol 2010;28: 893-901.

106 Aspinwall LG, Taber JM, Kohlmann W, Leaf SL, Leachman SA. Unaffected family members report improvements in daily routine sun protection 2 years following melanoma genetic testing. Genet Med 2014;16:846-53.

107 Rendleman J, Shang S, Dominianni C, Shields JF, Scanlon P, Adaniel C, Desrichard A, Ma M, Shapiro R, Berman R, Pavlick A, Polsky D, Shao Y, Osman I, Kirchhoff T. Melanoma risk loci as determinants of melanoma recurrence and survival. J Trans/ Med 2013;11:279.

108 Yin J, Liu H, Liu Z, Wang L-E, Chen WV, Zhu D, Amos Cl, Fang S, Lee JE, Wei Q. Genetic variants in fanconi anemia pathway genes BRCA2 and FANCA predict melanoma survival. J Invest Dermatol 2014;135:542-50. 